
Tailings

by

P. L. Koehmstedt

J. N. Hartley

D. K. Davis

January 1977

Prepared for the Energy Research and Development Administration under Contract EY-76-C-06-1830 
NOTICE

This report was prepared as an account of work sponsored by the United States Covernnent. Neither the United States nor the Energy Research and Development Admiristration, nur ally of their amployees, nor any of their contractors, subcontractors, or their employees, makes any warranty, express or implied, or assumes any legal liability or responsibility for the accuracy, completeness or usefulness of any information, apparatus, product or process disclosed, or represents that its use would not infringe privately owned rights.

\author{
PACIFIC NORTHWEST LABORATORY \\ operated by \\ BATTELLL \\ for the \\ ENERGY RESEARCH AND DEVELOPNIENT ADMIN:STRATION \\ Under Contract EY-75-C-06-1930
}

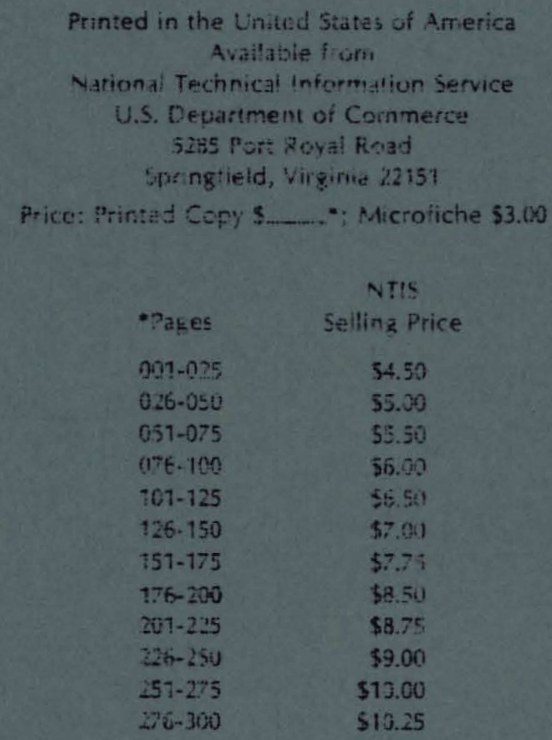


USE OF ASPHALT EMULSION SEALANTS

TO CONTAIN RADON AND RADIUM

IN URANIUM TAILINGS

by
inal
P. L. Koehmstedt
$3-11326$
Jim
J. N. Hartley
$5-270$
D. K. Davis

January 1977

\author{
BATTELLE \\ Pacific Northwest Laboratories \\ Richland, Washington 99352
}



The Energy Research and Development Administration (ERDA) sponsored work at Battelle, Pacific Northwest Laboratories (PNL) to evaluate asphalt emulsions as a sealant to retain radium in uranium mill tailings and to provide a barrier on the tailings surface to prevent radon diffusion to the atmosphere. Suitable asphalt emulsion tailings mixtures were formulated and radioisotope diffusion was measured. Also, a preliminary assessment of asphalt emulsion stability to ozone, oxidation, ultra violet (UV) and gamma radiation was made to determine any potential long-term deterioration.

The results of this study indicate the following:

- A 3.2-mm (1/8-in.) thick Armak E-63 or Armak 13 MR cationic asphalt emulsion tailings seal was very effective in preventing radon diffusion to the environment (tailings from the Vitro site in Salt Lake City, Utah and the United Nuclear site in Ambrosia Lake, New Mexico were used for experimental tests). A seal less than $3.2 \mathrm{~mm}$ would probably be very effective, but was not achievable with available laboratory equipment.

- Radon diffusion rates through a 3.2-mm asphalt emulsion seal were calculated to be about $9 \times 10^{-4} \mathrm{oCi} / \mathrm{cm}^{2} \mathrm{sec}$.

- A 6.4-mm (1/4-in.) thick Armak E-63 cationic asphalt emulsion tailings seal was capable of preventing radium, radon, and nitrogen permeation under $3.5 \mathrm{~kg} / \mathrm{cm}^{2}$ (50 psi) overpressure for 17 days.

- The physico-chemical properties of the tailings surface must be estabblished to identify asphalt emulsion and/or additive requirements for good radon seals.

- The moisture content of the tailings surface must be controlled to facilitate good emulsion penetration, and thus good seal formation.

- The integrity of the seal was not affected when the asphalt emulsion tailings seal was exposed to 19 freeze/thaw $\left(0\right.$ to $72^{\circ} \mathrm{F}$ ) cycles. 
- The integrity of the seal was not affected when the asphalt emulsion seal was exposed to $100,000 \mathrm{R}$ gamma radiation. The radiation exposure to the asphalt emulsion seal is not considered to cause breaching or lowering the integrity of the seal.

- Ultra violet radiation and oxygen exposures could result in deterioration of asphalt emulsion; however, a layer of soil which would be economical to apply would prevent the UV deterioration, which is most significant. To prevent effects of oxygen completely requires anaerobic burial depths of probably about $1.5 \mathrm{~m}(4.5 \mathrm{ft})$ or with high humus content $0.8 \mathrm{~m}(2.5 \mathrm{ft})$. Microorganisms are also capable of attacking asphalt, but the resulting degradation is very slow, less than 1 mil $(0.025 \mathrm{~mm})$ thickness of an asphalt surface was affected in 3 years under ideal bacteria conditions.

- Airless spray application of asphalt emulsion seems to offer the most promise compared to conventional air pressure spray equipment which would cause bubble formation from entrained air.

\section{RESEARCH RECOMMENDATIONS}

Laboratory tests indicate that radon diffusion barriers can be costeffective when cationic asphalt emulsion is applied to uranium tailings. A 3.2-mm thick cationic asphalt emulsion-tailings seal totally prevents radon diffusion while a $6.4-\mathrm{mm}$ thick cationic asphalt emulsion-subsoil seal totally prevents radium permeation. However, additional laboratory and field work is needed before widespread usage is made of cationic asphalt emulsion. The basic areas where additional R\&D is needed include:

- Tailings samples from other mining areas should be examined for physico-chemical properties to determine sealing formulation requirements. Samples should then be tested for radon and radium sealing capability.

- The effect of surface moisture on seal penetration and integrity should be investigated. 
- Greater emulsion penetration into tailings by water dilution or dilution with non-ionic asphalt emulsion should be tested to provide a thicker and more mechanically stable seal.

- The effect of various controllable variables (such as seal thickness) on radon and radium sealing should be evaluated.

- Radon diffusion measurements should be made in the field at selected uranium tailings locations using a sealed enclosure to measure the effectiveness of laboratory-developed sealing procedures.

- The use of air-blown asphalt as a feed stock for preparation of asphalt emulsion should be investigated since it could potentially increase the long-term stability of the asphalt emulsion (resistance to oxygen and ozone).

- Technology for appiying asphalt emulsion to tailings should be reviewed and the most promising techniques identified and field tested.

- Based on results of these field tests, a preliminary cost estimate should be made on the application of asphalt emulsions to tailings including contouring, prewetting, sealing, and covering with top soil for mechanical durability and reduced degradation due to UV, oxygen, ozone, etc. 
SUMMARY •

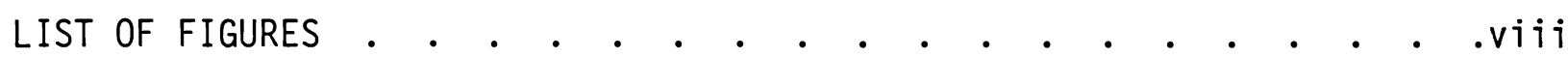

LIST OF TABLES $\quad$ •

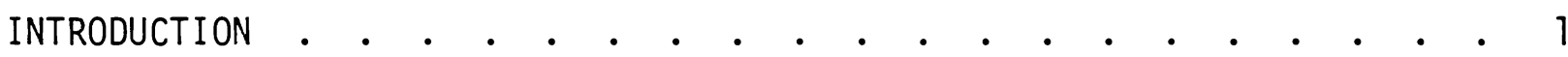

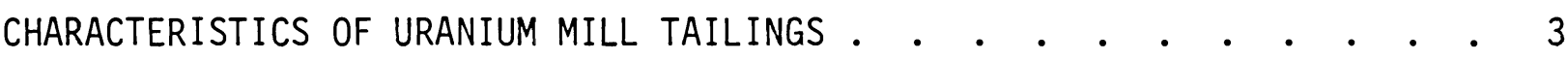

PROPERTIES OF TAILINGS •

RADIUM AND RADON IN URANIUM TAILINGS • • • • • • • • • • • • • •

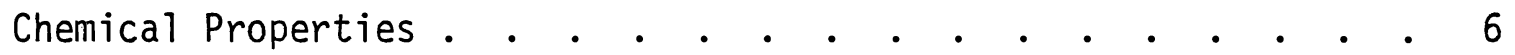

Nuclear Properties and Potential Hazards . . . . . . . . 8

FORMULATION OF ASPHALT EMULSION •

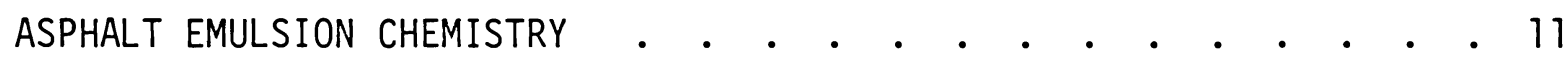

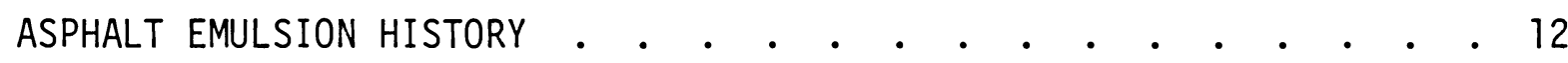

STABILITY OF THE ASPHALT EMULSION SEAL

DOSE ACCUMULATED BY URANIUM TAILINGS COVERINGS • • • • • • • • •

Surface Dose Rate from All Radiations to Tailings Covering • . 14

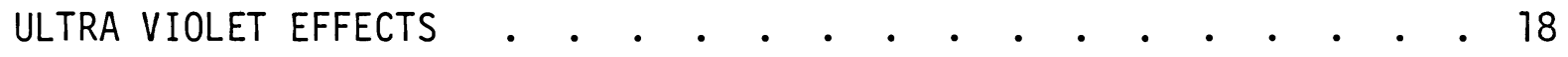

THE CYCLIC FREEZE/THAW • • • • • • • • • • • • • • • • • • • • 19

MICROBIAL ATTACK • • • • • • • • • • • • • • • • • • • 19

CHEMICAL ATTACK • • • • • • • • • • • • • • • • • • • • • •

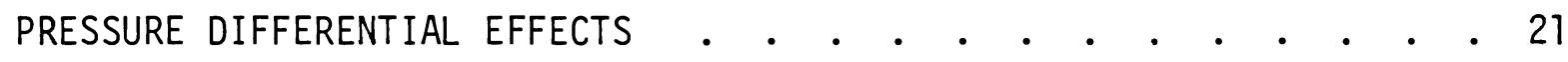

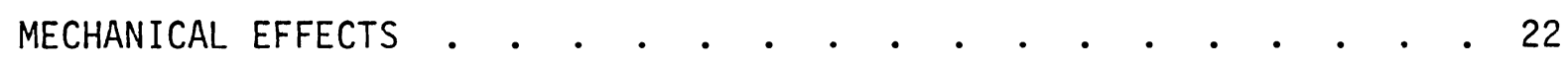

APPLICATION OF ASPHALT EMULSION FOR SEALING TAILINGS • • • • • • • • $\quad$ • 23

APPLICATION METHODS • • • • • • • • • • • • • • • • • • 23

Optimum Thickness • • • • • • • • • • • • • • • • • 24

LABORATORY EXPERIMENTAL WORK • • • • • • • • • • • • • • • • • •

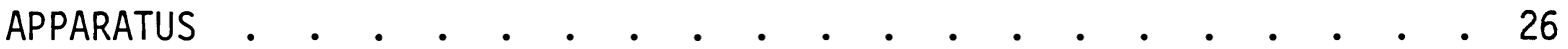

Radon Source • • • • • • • • • • • • • • • • • 26

Radon Diffusion Test Cell . . . . . . . . . . . . . 30

Radon Measurement System • • • • • • • • • • • • . • 31

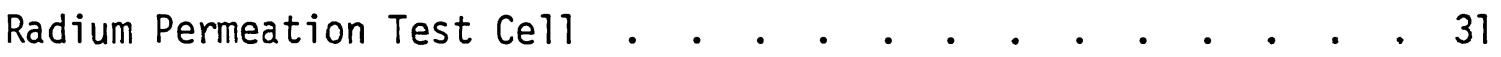




\section{CONTENTS (contd)}

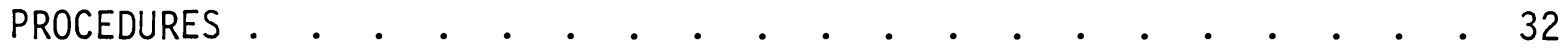

Radon Diffusion Seal Preparation and Installation . . . . . . 32

Radium Seal Test Procedure . . . . . . . . . . . 34

RADON AND RADIUM SEAL TEST RESULTS . • . . . . . . . . . . 36

Radon Diffusion Tests . . . . . . . . . . . . . 37

Radium Seal. . . . . . . . . . . . . . . . . . . 41

CONCLUSIONS. . . . . . . . . . . . . . . . . . . . . . . .

DISCUSSION OF SEALING MECHANISM . . . . . . . . . . . . . . . .

RESEARCH RECOMMENDATIONS . . . . . . . . . . . . . . . . . . 48

ADDITIONAL LABORATORY TESTING. . . . . . . . . . . . . . . 48

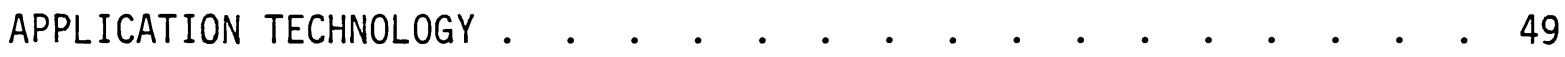

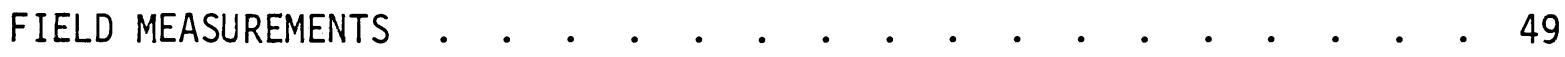

Short Term . . . . . . . . . . . . . . . . . . . 49

Long Term . . . . . . . . . . . . . . . . . . . 49

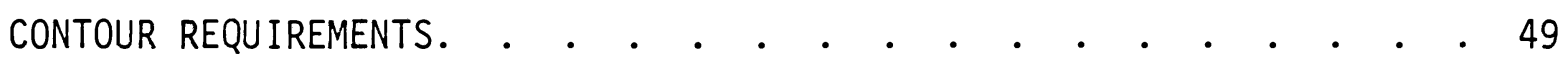

STABILITY . . . . . . . . . . . . . . . . . . . . 50

Chemical. . . . . . . . . . . . . . . 50

Mechanical . . . . . . . . . . . . . . 50

REFERENCES . . . . . . . . . . . . . . . . . . . . . . Ref-1

APPENDIX A - RADIUM-RADON TRANSPORT THROUGH ASPHALT EMULSION • • . . A-1

APPENDIX B - TYPICAL DATA TAKEN DURING LABORATORY EXPERIMENTS . . . . B- 1

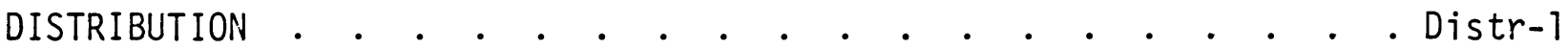




\section{LIST OF FIGURES}

1 Uranium-Radium Family . . . . . . . . . . . . . . 7

2 Basic Experimental Setup for Asphalt Emulsion Tailing Seal Radon Diffusion Tests . . . . . . . . . . . . . . . 27

3 Overall View of Diffusion Test Apparatus. . . . . . . . . 28

4 Radon Source . . . . . . . . . . . . . . . . . 28

5 Radon Diffusion Test Cell. . . . . . . . . . . . . . 29

6 Radon Measurement System . . . . . . . . . . . . 29

7 Radium Permeation Test Cell . . . . . . . . . . . . 30

8 Radon Diffusion Test Chamber. . . . . . . . . . . . 33

9 Radium Permeability Test Chamber . . . . . . . . . . . 35

10 Cationic Asphalt Emulsion Deposition . . . . . . . . . . 46

B-1 Typical Radon Measurements Taken During Experiment 6 . . . . B-4

B-2 Typical Background Radon Levels. . . . . . . . . . . B-5 


\section{$\underline{\text { LIST OF TABLES }}$}

1 Inactive Uranium Mill Tailings . . . . . . . . . . . . 3

2 Uranium Mill Tailings at the Vitro Site . . . . . . . . . 5

3 Chemical Composition of the Vitro Uranium Tailings . . . . . 5

4 The Vitro Uranium Tailings Size Distribution and $\mathrm{pH}$. . . . . 6

5 Properties of Radium Metal . . . . . . . . . . . . . 7

6 Properties of Radon. . . . . . . . . . . . . . . 8

7 Alpha Penetration Distance . . . . . . . . . . . . . 9

8 Number of Ionization . . . . . . . . . . . . . . . 9

9 The Uranium Series . . . . . . . . . . . . . . . . 15

10 Contribution of Radioisotopes to Surface Dose . . . . . . . 15

11 Estimated Surface Dose. . . . . . . . . . . . 16

12 Estimated Dose to Asphalt Emulsion in 1000 Years . . . . . . 17

13 Radon Diffusion Test Conditions. . . . . . . . . . 37

14 Planned Radon Seal Test Specimens . . . . . . . . . . . 41

15 Radium Seal Test Results . . . . . . . . . . . . . . 41

A-1 Permeability and Diffusion Constants for Water, Oxygen, and Radon... . . . . . . . . . . . . . .A-4

A-2 Radon and Radium Diffusion Rates Through Asphalt Emulsion . . . . . . . . . . . . . . . . . . .A-6

B-1 Typical Data Taken During Experiment 6R . . . . . . . .B-2

B-2 Experiment 6R (Vitro SS-10) . . . . . . . . . . . B-3 
• 
USE OF ASPHALT EMULSION SEALANTS TO CONTAIN

RADON AND RADIUM IN URANIUM TAILINGS

\section{$\underline{\text { INTRODUCTION }}$}

Currently, greater than $14,000 \mathrm{Ci}$ of ${ }^{226} \mathrm{Ra}$ are contained in about 23 million metric tons (MT) of tailings at 22 inactive uranium tailings sites in the western United States. ${ }^{1}$ The principal radiological implications and associated potential health hazards of these tailings appear to be related to the radionuclides of the ${ }^{238} \mathrm{U}$ decay chain, primarily ${ }^{230} \mathrm{Th}$, ${ }^{226} \mathrm{Ra},{ }^{222} \mathrm{Rn}$ (a noble gas), and ${ }^{222} \mathrm{Rn}$ progeny. The decay products with possible adverse effects to the general public from long-term exposure are ${ }^{226} \mathrm{Ra}$ and ${ }^{222} \mathrm{Rn}$. Radium 226, which is present as a solid or in solution, has a half-life of 1620 years and, therefore, should desirably be retained in the tailings for thousands of years. Radon 222 is a gas with a relatively short half-life of 3.8 days. Its concentration in the atmosphere can be controlled by containing it in the tailings for a few weeks.

Stabilization of the uranium tailings would minimize human exposures through inhalation and ingestion, but no simple stabilization procedures are available to adequately prevent exposure. Therefore, the Energy Research and Development Administration (ERDA) contracted Battelle, Pacific Northwest Laboratories (PNL) to evaluate the use of asphalt emulsion as a sealant to retain radium in the tailings and to provide a barrier on the tailings surface to prevent radon diffusion to the atmosphere. Laboratory studies included formulating suitable asphalt emulsion tailings mixtures, measuring radioisotope diffusion through asphalt emulsion-tailings seal, and making a preliminary assessment of the stability of asphalt emulsion (effects of ozone, oxidation, ultra violet (UV), and gamma radiation) to determine any long-term deterioration.

This report describes the results of this study including the characterization of uranium mill tailings and of radon and radium, the formulation 
of asphalt emulsions, radon and radium transport through asphalt emulsion, the stability of asphalt emulsion seals and the application of asphalt emulsion for sealing tailings, and laboratory experimental work conducted at PNL. The conclusions and recommendations summarize the status of the asphalt emulsion technique for controlling radium and radon in uranium mill tailings. Both general and specific recommendations are made for additional research that would enhance ERDA's options for stabilizing uranium tailings. 


\section{CHARACTERISTICS OF URANIUM MILL TAILINGS}

Twenty-two inactive tailings sites in the western U.S. contain from 82,000 metric tons (MT) to 2.5 million MT of uranium mill tailings (Table 1). Tailings at these sites total about 23 million MT.

TABLE 1. Inactive Uranium Mill Tailings (1)

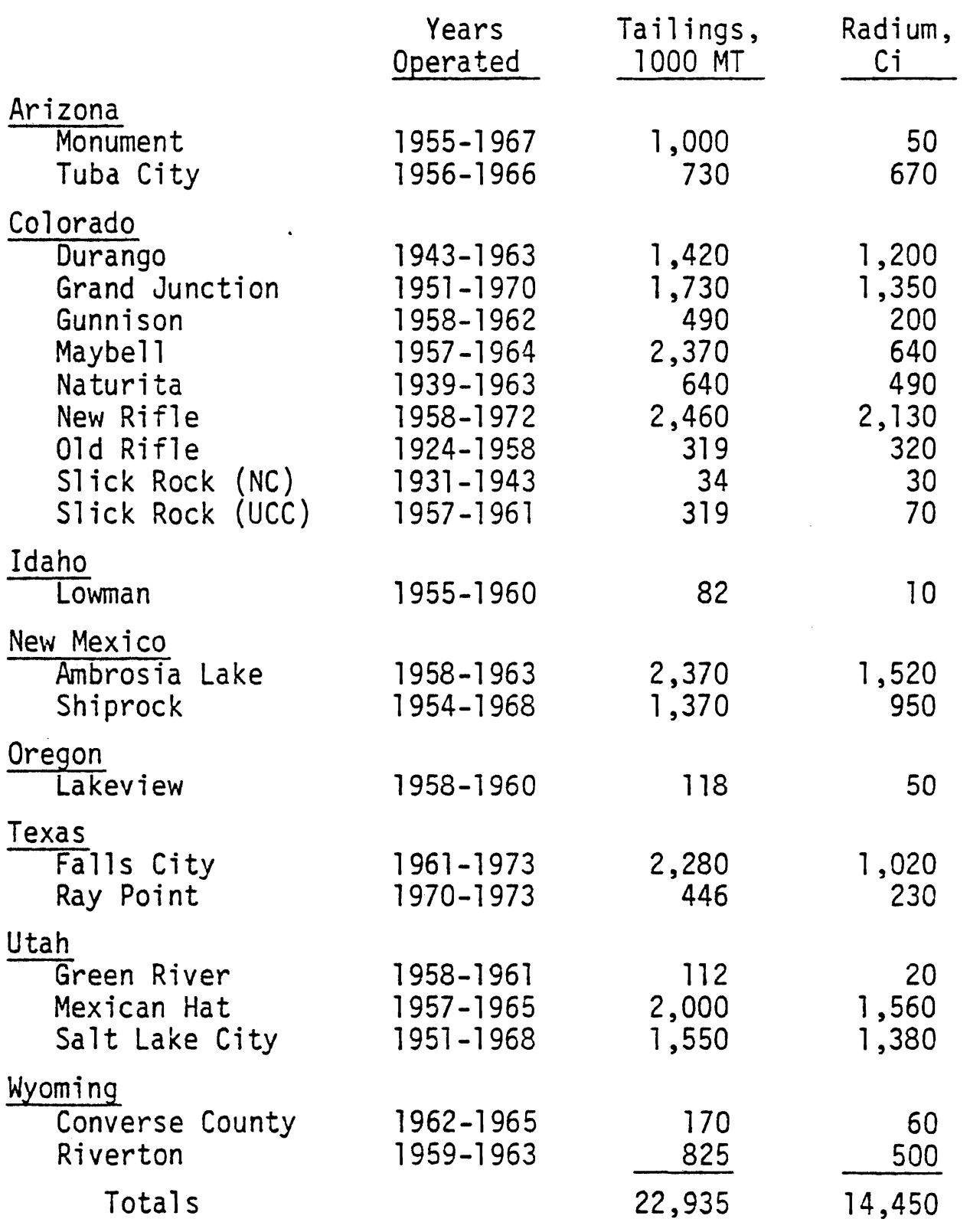


of these 22 sites available for sampling, two inactive tailing sites were selected. The Vitro site at Salt Lake City, Utah was selected because of the urgent need to find a solution to the problem of radon emanating from a uranium tailings pile in a metropolitan area and the unsatisfactory site conditions that involve most of the problems expected at other locations. The unstabilized mill tailings pile at this site, which is located in the center of the Salt Lake Valley population, is mostly uncovered and is subject to continuous wind and minor water erosion. The United Nuclear Ambrosia Lake site at Grants, New Mexico was selected because it is typical of tailings resulting from processing ore by the carbonate leach process resulting in sealing problems that are different from the Vitro sites or other acid leach tailings.

Ten samples were taken at each site in order to be representative of the uranium tailings. Sample locations were selected to cover the wide range of materials found at these sites including slimes, sewage sludge and typical sand-like tailings.

\section{PROPERTIES OF TAILINGS}

Several types of material make up the Vitro tailings pile although uranium tailings are by far the most abundant. Table 2 lists the types of material presently on the site as well as their volume and weight, while Table 3 lists the chemical content of the uranium and vanadium tailings. The water and soil taken from onsite test holes is primarily acidic as can be seen in Table 4. The tailings have a fine size distribution (300 to $75 \mu \mathrm{m})$ with a high clay content that is relatively impermeable and difficult to dewater. Analyses of samples from bore holes indicate that the uranium tailings were not deposited uniformly in the ponds. This nonuniformity can be attributed to changes in the milling process, the variety of ore sources, and the differential deposit and migration of slimes from the tailings discharge points.

Currentiy, no detailed data has been reported on United Nuclear's Ambrosia Lake Area, Grants, New Mexico. The tailings at this site resulted from processing uranium ores using the carbonate leach process so they should be a somewhat smaller particle size than the Vitro tailings. 
TABLE 2. Uranium Mill Tailings at the Vitro Site (2)

\begin{tabular}{|c|c|c|}
\hline Material & Volume, $M^{3}$ & Weight, MT \\
\hline $\begin{array}{l}\text { Uranium Tailings } \\
\text { Vanadium Tailings } \\
\text { Dikes } \\
\text { Rubble Moved to Site } \\
\text { Sewage Sludge }\end{array}$ & $\begin{array}{r}1,090,000 \\
81,500 \\
80,000 \\
62,000 \\
6,200 \\
\end{array}$ & $\begin{array}{r}1,710,000 \\
128,000 \\
141,000 \\
107,000 \\
2,900 \\
\end{array}$ \\
\hline Total & $1,319,700$ & $2,089,900$ \\
\hline
\end{tabular}

TABLE 3. Chemical Composition of the Vitro Uranium Tailings (2)

\begin{tabular}{lcc}
\multicolumn{1}{c}{ Element } & $\begin{array}{c}\text { Composite } \\
\text { Uranium Sample, } \%\end{array}$ & $\begin{array}{c}\text { Composite } \\
\text { Vanadium Sample, } \%\end{array}$ \\
Antimony &.- & 0.016 \\
Arsenic & 0.021 & 0.023 \\
Barium & 0.213 & 0.386 \\
Bismuth & 0.006 & 0.012 \\
Chromium & 0.101 & 0.203 \\
Cobalt & 0.003 & 0.016 \\
Copper & 0.031 & 0.108 \\
Gold & 3.110 & 0.00021 \\
Iron & 0.306 & 21.63 \\
Lead & 0.033 & 0.035 \\
Manganese & 0.033 & 0.210 \\
Molybdenum & 0.055 & 0.055 \\
Nickel & 0.056 & 0.107 \\
Rubidium & 0.00022 & 0.022 \\
Silver & 0.413 & 0.00066 \\
Strontium & 0.006 & 0.187 \\
Tin & 0.566 & 0.62 \\
Titanium & 0.057 & 0.511 \\
Tungsten & 0.018 & 0.018 \\
Uranium $\left(\mathrm{U}_{3} \mathrm{O}_{8}\right)$ & 0.010 & 0.005 \\
Vanadium & 0.034 & 0.083 \\
Zinc & 0.042 & 0.035 \\
Zirconium & & 0.020
\end{tabular}


TABLE 4. The Vitro Uranium Tailings Size Distribution and $\mathrm{pH}^{(2)}$

\begin{tabular}{|c|c|c|c|c|c|c|c|c|}
\hline \multirow[b]{3}{*}{$\begin{array}{l}\text { U.S. Standard } \\
\text { Sieve Number }\end{array}$} & \multicolumn{8}{|c|}{ Sample Numbers } \\
\hline & \multicolumn{2}{|c|}{ SV-2 } & \multicolumn{2}{|c|}{ SV-9 } & \multicolumn{2}{|c|}{$S V-12$} & \multicolumn{2}{|c|}{ SV-74 } \\
\hline & $\begin{array}{l}\text { Uranium, } \\
\% \text { Passing }\end{array}$ & $\begin{array}{c}\% \\
\text { water } \\
\text { water }\end{array}$ & $\begin{array}{l}\text { Uranium, } \\
\% \text { Passing }\end{array}$ & 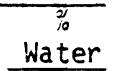 & $\begin{array}{l}\text { Uranium, } \\
* \text { Passing }\end{array}$ & $\begin{array}{c}\% \\
\text { Water }\end{array}$ & $\begin{array}{l}\text { Vanadium, } \\
\because \text { Passing }\end{array}$ & $\begin{array}{l}\% \\
\text { Water } \\
\text { W. }\end{array}$ \\
\hline $\begin{array}{r}50(300 \mathrm{um}) \\
100(150 \mathrm{~m}) \\
200(75 \mathrm{~mm})\end{array}$ & $\begin{array}{l}94 \\
75 \\
54\end{array}$ & $(3.50)^{(a)}$ & $\begin{array}{l}80 \\
51 \\
34\end{array}$ & $(25.8)$ & $\begin{array}{l}98 \\
93 \\
91\end{array}$ & $(44.6)$ & $\begin{array}{l}53 \\
29 \\
15\end{array}$ & $(15.6)$ \\
\hline
\end{tabular}

\begin{tabular}{|c|c|c|}
\hline Test Hole & $\mathrm{pH}$ of Water & $\begin{array}{r}\mathrm{pH} \text { of Soil } \\
(5 \% \text { water by wt) }\end{array}$ \\
\hline$S V-1$ & 7.38 & -- \\
\hline SV -3 & 3.50 & \\
\hline$S V-4$ & $=$ & 5.10 \\
\hline SV -5 & 3.75 & 6.43 \\
\hline SV-7 & 6.18 & -- \\
\hline SV -9 & & 6.38 \\
\hline SV -10 & 6.90 & 4.00 \\
\hline $5 V-13$ & 7.20 & - \\
\hline SV -15 & 3.65 & -- \\
\hline SV-16 & 7.35 & -. \\
\hline SV-18 & 4.10 & $=-$ \\
\hline SV-19 & & 7.50 \\
\hline$S V-24$ & 8.15 & -- \\
\hline$S V-15$ & -- & 6.18 \\
\hline
\end{tabular}

(a) ( ) \% water in total sample.

RADIUM AND RADON IN URANIUM TAILINGS

Uranium mill tailings will be radioactive virtually indefinitely due to the ${ }^{238} \mathrm{U}$ daughter ${ }^{230}$ Th which has a long half-life of $80,000 \mathrm{yr}$ (see Figure 1). This ${ }^{230} \mathrm{Th}$ will ensure a nearly indefinite supply of ${ }^{226} \mathrm{Ra}$ which will, in turn, ensure a supply of ${ }^{222} \mathrm{Rn}$. The presence of ${ }^{222} \mathrm{Rn}$ and ${ }^{226} \mathrm{Ra}$ in the tailings dose pose a potential hazard to the population near the tailings.

Chemical Properties

Chemically, radium is very similar to barium and calcium. They are al1 members of the same periodic group (11A) and have a +2 valence, which is characteristic of this chemical group; Table 5 shows some select properties of metallic radium. More than $90 \%$ of the radium content of the original ore goes to the uranium mill tailings. (3) Only a minor amount of radium 


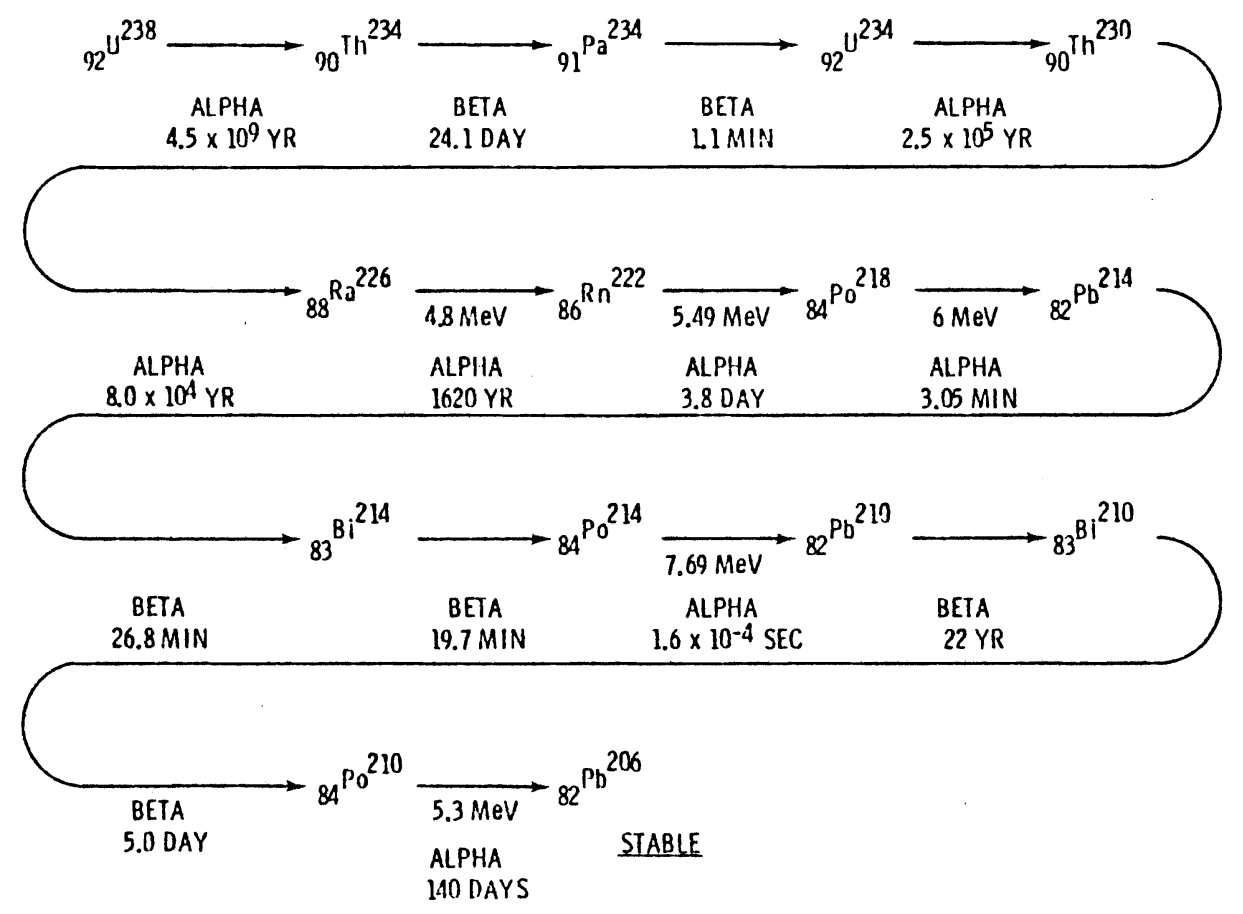

FIGURE 1. Uranium-Radium Family ${ }^{(4)}$

is leached out of the ore during processing by sulfuric acid $\left(\mathrm{H}_{2} \mathrm{SO}_{4}\right)$, by sodium carbonate $\left(\mathrm{Na}_{2} \mathrm{CO}_{3}\right)$, and sodium bicarbonate $\left(\mathrm{NaHCO}_{3}\right)$ leaching.

The predominate compounds found $\left(\mathrm{RaSO}_{4}\right.$ or $\mathrm{RaCO}_{3}$ ) in tailings are fairly insoluble in most aqueous solutions which helps to restrict their leaching from the tailings, thus reducing the amount of radium that could be transported to the surrounding environment. The solubility of $\mathrm{RaSO}_{4}$ is $0.0014 \mathrm{mg} / \mathrm{g} \mathrm{H}_{2} \mathrm{O}^{(6)}$ while the solubility of $\mathrm{RaCO}_{3}$ is about $0.22 \mathrm{mg} / \mathrm{g} \mathrm{H}_{2} \mathrm{O}$. $(7,8)$

TABLE 5. Properties of Radium Metal ${ }^{(5)}$

Atomic weight

Specific gravity

Melting point

Boiling point

Ionic Radium

Color
226.025

$5 \mathrm{~g} / \mathrm{cm}^{3}$

$700{ }^{\circ} \mathrm{C}$

$1140{ }^{\circ} \mathrm{C}$

$1.43 \AA$

silver white 
Radon is the heaviest of the noble gases, some 7.7 times denser than air, and since it is a noble gas its ability to form compounds is nearly zero. (a) The radon in the tailings is a pure inert gas that can move freely. Table 6 gives some select properties of radon.

TABLE 6. Properties of Radon $(5,9)$

$\begin{array}{lr}\text { Atomic weight } & 222 \\ \text { Density (gas) } & 9.7 \mathrm{~g} / \ell \\ \text { Atomic radius } & 2.29 \AA \\ \text { Melting point } & -71{ }^{\circ} \mathrm{C} \\ \text { Boiling point } & -61.8^{\circ} \mathrm{C} \\ \text { Color } & \text { Colorless (gas) } 25^{\circ} \mathrm{C} \\ \text { Critical temperature } & 104.4{ }^{\circ} \mathrm{C} \\ \text { Critical pressure } & 62.4 \mathrm{Atm}\end{array}$

Radon is soluble in water, although the solubility decreases with increased temperature. The solubility is $0.51 \mathrm{~cm}^{3} / \mathrm{g} \mathrm{H}_{2} \mathrm{O}$ at $0^{\circ} \mathrm{C}$ and $0.085 \mathrm{~cm}^{3} / \mathrm{H}_{2} \mathrm{O}$ at $60^{\circ} \mathrm{C}{ }^{(8)}$ Assuming the gas $1 \mathrm{aw}$ and $1 \mathrm{~atm}$ pressure, these values convert to $\frac{0.5113 \mathrm{mg}}{\mathrm{g} \mathrm{H}_{2} \mathrm{O}}$ and $\frac{0.069 \mathrm{mg}}{\mathrm{g} \mathrm{H}_{2} \mathrm{O}}$, respectively.

Nuclear Properties and Potential Hazards

Both ${ }^{226} \mathrm{Ra}$ and ${ }^{222} \mathrm{Rn}$ give off alpha particles when they decay. Since alpha particles have a small penetration range, and are composed of two protons and two neutrons, they are considered heavy radiation particles. As they travel through tissue they strip neutral molecules of their outer electrons. This can cause biological damage if the ion removal is concentrated. Table 7 gives the penetration distances for various energy alphas in tissue while Table 8 gives the approximate number of electrons removed

(a) There have been some radon-fluorine compounds produced, but these were produced under very restrictive conditions. 
by alpha particles of various energy. The decline of ionizations during an increase of alpha energy is due to the shorter time the higher alpha particle influences each atom.

TABLE 7. Alpha Penetration Distance $(10)$

\begin{tabular}{cc} 
MeV & $\begin{array}{c}\text { Distance, } \\
\text { microns }(\mu)\end{array}$ \\
\hline 5.30 & 38.9 \\
5.49 & 41.7 \\
6.00 & 47.0 \\
7.69 & 70.8
\end{tabular}

TABLE 8. Number of Ionization (10)

\begin{tabular}{|c|c|}
\hline $\mathrm{MeV}$ & $\begin{array}{l}\text { Number of } \\
\text { Ionization } \\
\mu \text { of Tissue } \\
\end{array}$ \\
\hline $\begin{array}{l}1 \\
2 \\
3 \\
4 \\
5 \\
6\end{array}$ & $\begin{array}{l}5,207 \\
2,883 \\
2,031 \\
1,581 \\
1,301 \\
1,109\end{array}$ \\
\hline
\end{tabular}

Although radium has 16 known isotopes, we are only interested in ${ }^{226} \mathrm{Ra}$ which is a daughter of ${ }^{230} \mathrm{Th}$ (a daughter of ${ }^{238} \mathrm{U}$ ). The half-life of ${ }^{226} \mathrm{Ra}$ is 1620 years. When it decays ${ }^{226}$ Ra gives off a $4.8-\mathrm{MeV}$ alpha particle which can be introduced to the body through the food cycle. Due to its similarity to calcium, radium will then concentrate in the bones and teeth. The gamma radiation and alpha particles released by the decay of radium will affect the blood-producing mechanisms in the bones.

Upon decay, ${ }^{226} \mathrm{Ra}$ forms ${ }^{222} \mathrm{Rn}$, one of 20 known radon isotopes. Radon-222 has the longest half-life of any radon isotope (3.82 days), and releases a $5.48-\mathrm{MeV}$ alpha particle when it decays. Radon can either be introduced to the body by ingestion or by inhalation. Since radon's daughters are solids, they will imbed themselves in the tissue: Inhaled 
radon imbeds itself in the respiratory system, but will decay, given sufficient time. Several of radon's daughters decay by releasing energetic alpha particles that will cause large numbers of ions. These ions could cause tumors that could shorten the life of the exposed individual.

The recommended maximum allowable total drinking water content of radium is $5 \mathrm{\rho Ci} / \ell^{(11)}$ while the maximum permissible working concentration for radon is $3 \times 10^{-8} \mu \mathrm{Ci} / \mathrm{ml}$. (12) These are small amounts of materials which reflect the toxicity of these elements. As can be seen from this discussion, drinking water containing leach radium or breathing radon could pose a hazard to the populace near uranium tailings piles. Therefore, these uranium tailings piles should be efficiently sealed to reduce the hazard to the population from radium and radon. This seal could be provided by asphalt emulsion. 


\section{FORMULATION OF ASPHALT EMULSION}

Asphalt emulsions are homogeneous mixtures of small asphalt droplets suspended in a continuous water phase. These types of emulsions are usually termed oil-in-water $(0 / w)$ emulsions. They are prepared with a high speed, high shear mechanical device, such as a colloid mill. The colloid mill breaks down molten asphalt into small droplets in the presence of water and a chemical, surface-active emulsifier. This emulsifier imparts its properties to the dispersed asphalt and is most influential in maintaining stable asphalt droplet suspension.

\section{ASPHALT EMULSION CHEMISTRY}

The chemistry and preparation methodology of charged asphalt emulsions are described in a paper by Dybalski. (13) The three chemical components of emulsified asphalt are asphalt, water, and the emulsifier which are joined together by the mechanical influence of a colloid mill. Asphalts are colloidal dispersions of high molecular-weight aromatic hydrocarbons called asphaltenes. These asphaltenes are dispersed in a continuous phase of lower molecular-weight oily-resinous material (paraffins and aromatic resins) called maltenes. Using an optimum emulsifier concentration, acceptable asphalt emulsion provides an average particle size and distribution of $28 \%$ at $<1 \mu, 57 \%$ at 1 to $5 \mu$, and $15 \%$ at 5 to $10 \mu$. (13)

Water is an important component of asphalt emulsion since it can possess chemical ionic constituents that can either be beneficial or detrimental to the formation of a stable asphalt emulsion. For example, the presence of calcium and magnesium ions $\left(\mathrm{Ca}^{++}\right.$and $\mathrm{Mg}^{++}$) could benefit the formation of a stable cationic asphalt emulsion, but could be detrimental to the formation of anionic emulsion formulations because of the formation of water-insoluble calcium and magnesium salts. The presence of particulate matter in water could also be detrimental to the formation of a cationic emulsion due to rapid adsorption of cationic surfactants by the usually negatively-charged particulate matter. 
When present in very low concentrations, surface-active agents (surfactants) possess the unique property of altering the surface energy of their solvents, usually lowering rather than increasing the surface energy. Surface-active chemicals are soluble substances that markedly change the properties of the solvent and the surfaces they contact. There are three basic types of chemical surface-active agents which are classified according to their dissociation characteristics in water. These are anionic, nonionic, and cationic surfactants.

The emulsifier or surfactant is the most important component of any asphalt emulsion. To be an effective emulsifier for asphalt, a surfactant must be water soluble and must possess a proper balance between the hydrophilic and lipophilic properties. When used in combination with an acceptable asphalt, a good quality water, and adequate mechanical input, the emulsifier is the major factor which influences initial emulsification, emulsion stability, and ultimate field performance.

Dybalski(13) describes a correlation technique for application of asphalt emulsions through the use of zeta-potential determination of emulsion and application surface. In this manner emulsion bonding strength, set time, and penetration can be controlled at least in part by emulsion selection. The receiving surface zeta potential ( + or - ) determines if cationic or anionic type asphalt emulsion is to be used. To a large degree, the asphalt emulsion zeta potential determines the set time and the allowable penetration as well as bond strength. The higher the charge opposite to the receiving surface, the higher the bond strength, the more rapid the setting, and the lower the penetration. Presently, there are 10 cationic asphalt emulsions on the market ranging from +12 to $+130 \mathrm{mV}$ zeta potential, and 4 anionic asphalt emulsions ranging from -15 to $-80 \mathrm{mV}$ zeta potential.

\section{ASPHALT EMULSION HISTORY}

Asphalt deposits have been known and utilized by man for centuries. Some deposits are in the form of tar sands (for example, Athabaska Tar Sands in Alberta, Canada), pits or springs (for example, Rancho-1a-Brea Asphalt 
Pits in California and Al-Kwait in Arabia), or rock asphalt (Valde County, Texas). The large majority of asphalt used today results from refining crude oil.

The earliest recorded use of asphalt (about 3800 B.C.) was by the preBabylonian inhabitants of the Euphrates Valley in southeastern Mesopotania (presently Iraq). A legend passed down through the ages indicated that the infant King Sargan was placed in a reed basket coated with asphalt by his mother Itti-Bell (a Priestas) and set adrift on the Euphrates River during flooding. $(14,15)$ This legend corresponds closely with the tale of Moses which later appeared in the Bible.

The earliest recovered asphalt item was the bust of Manishtusu, King of Kish (about 3600 B.C.) ${ }^{(16-20)}$ which was found in excavations at Susa, Persia. The bust, supposedly transported by an Elanite conqueror in the 12th century.B.C., had its limestone eyes in place with asphalt. Numerous ornaments, $(21-25)$ figurines, $(26-32)$ statutes, $(33,34)$ ceremonial baths, $(35-38)$ and pavements ${ }^{(39-45)}$ involving asphalt, at least in part, from the 3500-2900 B.C. era have been excavated. These objects were recovered in excellent condition attesting to the potential long-term stability of asphalt under anaerobic burial conditions.

In 1910, Schade van Westrum obtained a patent ${ }^{(46)}$ for the application of bituminous dispersions in water for road building. Since then, the patent literature on the preparation and application of bitumen emulsions has grown enormously. Phillip published a survey of 1392-issued patents in 1938 . (47) 


\section{STABILITY OF THE ASPHALT EMULSION SEAL}

DOSE ACCUMULATED BY URANIUM TAILINGS COVERINGS $(\mathrm{a})$

According to Sears et al., ${ }^{(48)}$ uranium ore tailings generally contain 50 to $400 \mu \mathrm{g} / \mathrm{g}\left(20\right.$ to $\left.130 \times 10^{-6} \mu \mathrm{Ci} ; U_{\text {nat } /} \mathrm{g}\right)$, and 150 to $1000 \times 10^{-6} \mu \mathrm{Ci} / \mathrm{g}$ each of ${ }^{226} \mathrm{Ra},{ }^{230} \mathrm{Th}$ and $210 \mathrm{~Pb}$, depending on how rich an ore was processed. For purposes of dose estimation, it is assumed that the dose from $U_{\text {nat }}$ is from ${ }^{238} U$ and its daughters. The other radionuclide chain represented, beginning with ${ }^{235} U$ and ending with ${ }^{207} \mathrm{~Pb}$, contributes only about $5 \%$ of the total radioactivity, and is therefore neglected. It is further assumed that the ${ }^{238} \mathrm{U}$ decay chain is in secular equilibrium, an assumption borne out by actual measurement of the ${ }^{230} \mathrm{Th}$ and ${ }^{226} \mathrm{Ra}$ in the tailings. $(49,50)$

No account was taken of any possible concentration of radioactivity in the tailings. Rather, the total radioactivity was assumed to be uniformly divided between the sands, the slimes, and the dissolved material. Since it is known, for example, that the slimes at each inactive tailings sites contain radioactivity 10 to 100 times the average concentration, then all subsequent dose calculations for the average concentration can be multiplied by 10 to 100 for a better estimate of the dose to the tailings covering.

Table 9 identifies the uranium series and lists the Q's (the decay energies) as tabulated in the Table of Isotopes. (51) The $Q$ values are somewhat higher (by a few percent) than the total energy available for irradiating the tailings covering, but do not underestimate this dose.

Surface Dose Rate from All Radiations to Tailings Covering

In a system large enough to establish radiation equilibrium, the dose to a point in that medium is obtained from the conservation of energy. The dose on the surface (which also represents sufficiently well the dose to

(a) F. T. Cross, Battelle, Pacific Northwest Laboratories, was the principal author of this section. 
TABLE 9. The Uranium Series

\begin{tabular}{|c|c|c|c|c|c|}
\hline Isotope & Symbol & $\begin{array}{l}\text { Historical } \\
\text { Name }\end{array}$ & $\mathrm{Half}-1 \mathrm{ife}$ & Radiation & Total $Q(\mathrm{MeV})$ \\
\hline $\begin{array}{l}\text { Uranium-238 } \\
\text { Thorium-234 }\end{array}$ & $\begin{array}{l}238 \mathrm{U} \\
234_{T h}\end{array}$ & $\begin{array}{l}\text { Uranium } I \\
\text { Uranium } x_{1}\end{array}$ & $\begin{array}{l}4.5 \times 10^{9} \mathrm{yr} \\
24.1 \text { days }\end{array}$ & $\begin{array}{l}\alpha \\
\beta, \gamma\end{array}$ & $\begin{array}{l}4.2 \\
0.263\end{array}$ \\
\hline Protactinium-234 & ${ }^{234} \mathrm{~Pa}$ & Uranium $x_{2}$ & $1.18 \mathrm{~min}$ & $\beta, \gamma$ & 2.23 \\
\hline Uranium-234 & $234 U$ & Uranium II & $2.50 \times 10^{5} \mathrm{yr}$ & $\alpha, \gamma$ & 4.856 \\
\hline $\begin{array}{l}\text { Thor ium-230 } \\
\text { Radium-226 }\end{array}$ & $\begin{array}{l}230 \\
226_{\mathrm{Ra}}\end{array}$ & $\begin{array}{l}\text { Ionium } \\
\text { Radium }\end{array}$ & $\begin{array}{l}7.6 \times 10^{4} \mathrm{yr} \\
1620 \mathrm{yr}\end{array}$ & $\begin{array}{l}\alpha \\
\alpha, \gamma\end{array}$ & $\begin{array}{l}4.767 \\
4.869\end{array}$ \\
\hline $\begin{array}{l}\text { Radon-222 } \\
\text { Polonium-218 } \\
\text { Lead-214 }\end{array}$ & $\begin{array}{l}222 \mathrm{Pn} \\
218 \mathrm{Po} \\
214 \mathrm{~Pb}\end{array}$ & $\begin{array}{l}\text { Radon } \\
\text { Radium A } \\
\text { Radium B }\end{array}$ & $\begin{array}{l}3.82 \text { days } \\
3.05 \mathrm{~min} \\
26.8 \mathrm{~min}\end{array}$ & $\begin{array}{l}a \\
a \\
\beta, \gamma\end{array}$ & $\begin{array}{l}5.587 \\
6.111 \\
1.04\end{array}$ \\
\hline Bismuth-214 & $274_{8 i}$ & Radium C & $19.7 \min$ & $B, \gamma$ & 3.28 \\
\hline $\begin{array}{l}\text { Polonium-214 } \\
\text { Lead-210 }\end{array}$ & $\begin{array}{l}214 \mathrm{Po}^{2} \\
210_{\mathrm{Pb}}\end{array}$ & $\begin{array}{l}\text { Radium } C^{\prime} \\
\text { Radium } D\end{array}$ & $\begin{array}{l}164 \times 10^{-6} \mathrm{sec} \\
22.0 \mathrm{yr}\end{array}$ & $\begin{array}{l}\alpha \\
\beta, \gamma\end{array}$ & $\begin{array}{l}7.835 \\
0.061\end{array}$ \\
\hline $\begin{array}{l}\text { Bismuth-210 } \\
\text { Polonium-210 } \\
\text { Lead-206 }\end{array}$ & $\begin{array}{l}210_{\mathrm{Bi}} \\
210_{\mathrm{PO}} \\
206_{\mathrm{Pb}}\end{array}$ & $\begin{array}{l}\text { Radium } E \\
\text { Radium } F \\
\text { Radium } G\end{array}$ & $\begin{array}{l}5.0 \text { days } \\
138.4 \text { days } \\
\text { Stable }\end{array}$ & $\begin{array}{l}\beta \\
\alpha\end{array}$ & $\begin{array}{l}1.160 \\
5.408\end{array}$ \\
\hline
\end{tabular}

the material covering that surface) is just one-half of this value. The equation describing the surface dose for large bodies is:

$$
D(\mathrm{rad} / \mathrm{hr})=\frac{2.13}{2} \mathrm{EC}
$$

where $E$ is the decay energy in MeV per disintegration and $C$ is the concentration of the radioisotope in $\mu \mathrm{Ci} / \mathrm{g}$. The contribution to the surface dose of the various constituents in the tailings is tabulated in Table 10.

TABLE 10. Contribution of Radioisotopes to Surface Dose

$\begin{array}{ll}\frac{\text { Radioisotope }}{\text { Nat } U} & \rightarrow \frac{\text { Dose, Rad/yr }}{230 \mathrm{Th}} \\ 226 \mathrm{Ra} & \rightarrow 56 \text { to } 374 \\ 210 \mathrm{~Pb} & \rightarrow 49 \text { to } 330 \\ \text { Total } & \Sigma=\frac{9 \text { to } 62}{122 \text { to } 830}\end{array}$


For purposes of estimating radiation damage or integrity of the tailings covering, it is considered sufficiently accurate to round these values to $10^{2}$ to $10^{3} \mathrm{rad} / \mathrm{yr}$. Since the majority ( $95 \%$ ) of this dose comes from the alphas, only the first $20 \mu \mathrm{m}(0.001 \mathrm{in}$.$) or so of the covering will be$ subjected to radiation insult, ranging from $10^{2}$ to $10^{3} \mathrm{rad} / \mathrm{yr}$ at the surface to approximately 0 at about $0.001 \mathrm{in}$.

Estimation of Gamma Only Dose Rate to Tailings Covering

Using Equation (2) and the mean gamma energy from the radioactive constituents, surface doses are estimated (see Table 11). Since the average depth of tailings is $4.8 \mathrm{~m},(52)$ the calculated dose $3 \mathrm{ft}$ above the surfaces of tailings is about 0.2 to $1.1 \mathrm{mrad} / \mathrm{hr}$. Measurements of the gamma dose rate $3 \mathrm{ft}$ above tailings usually range from 0.5 to $1.6 \mathrm{mR} / \mathrm{hr}(53)$ (here, $1 \mathrm{mR} \simeq 1 \mathrm{mrad}$ ). This is in good agreement with the above calculations.

\section{TABLE 11. Estimated Surface Dose}

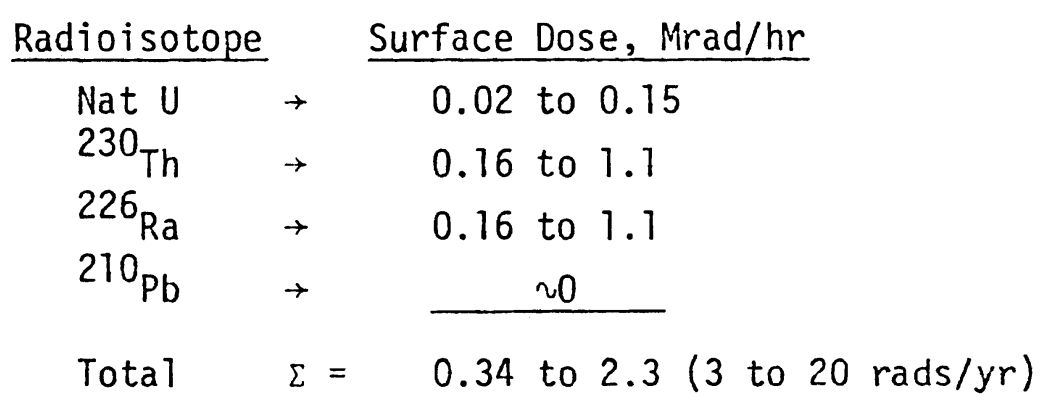

Upper Estimation of Radon and Daughters Dose Rate to Tailings Covering Although it is inconceivable that ${ }^{226} \mathrm{Ra}$ gas would concentrate just under an impervious cover, but would rather distribute itself according to partial pressure differences, an upper estimate of the dose was made for just this condition. According to Schiager, ${ }^{(54)}$ the maximum rate of radon emission from tailings is $1.6 \times 10^{-4} \mathrm{pCi} / \mathrm{cm}^{2} \cdot \mathrm{s}$ per $\mathrm{pCi} / \mathrm{g}{ }^{226} \mathrm{Ra}$ in the tailings. Therefore, in $10^{3}$ yr the ${ }^{222}$ Rn activity leaving the tailings is $5.05 \times 10^{6} \mathrm{pCi} / \mathrm{cm}^{2}$. Assuming all of this radioactivity is trapped and decays just under the covering, the thin planar source equation may be used for estimating the dose to the covering. The equation is: 


$$
D=\frac{I E}{2 p R}\left[1+\ln \left(\frac{R}{X}\right)\right]
$$

where $I$ = disintegration rate per unit area of tailings surface

$E=$ average alpha energy per disintegration

$\rho=$ density of covering $\left(1.6 \mathrm{~g} / \mathrm{cm}^{3}\right.$ assumed for an asphalt covering)

$R=$ range of alpha in covering

$X=$ distance from the uniform alpha emitting plane and never exceeds R.

The ranges of the alphas are estimated from the range-energy relationships in tissue, correcting for density and atomic number differences, and are from about $24 \mu \mathrm{m}$ for ${ }^{210} \mathrm{Po}$ to $44 \mu \mathrm{m}$ for ${ }^{214} \mathrm{Po}$. Assuming a ${ }^{226} \mathrm{Ra}$ concentration of $1 \mathrm{pCi} / \mathrm{g}$ and radioactive equilibrium conditions, Equation (3) predicts the dose contributions 1 isted in Table 12, averaged in a thickness of asphalt equal to the range of the alphas.

TABLE 12. Estimated Dose to Asphalt Emulsion in 1000 Years

$\begin{array}{lll}\frac{\text { Radioisotope }}{222} & \frac{\text { Dose, Rads in } 1000 \mathrm{yr}}{\mathrm{Rn}} \\ 218 \mathrm{Po} & \rightarrow & 9.5 \times 10^{+5} \\ 214 \mathrm{Po}_{\mathrm{Po}} & \rightarrow & 5.0 \times 10^{+2} \\ 210 \mathrm{Po} & \rightarrow & 3.8 \times 10^{-4} \\ & 3.5 \times 10^{+7}\end{array}$

Since the ${ }^{226} \mathrm{Ra}$ concentration ranges from 317 to $2133 \mathrm{pCi} / \mathrm{g}$, the dose to the asphalt covering ranges from about $10^{10}$ to $10^{11} \mathrm{rads} / 10^{3} \mathrm{yr}$. This dose accrues to only the first $24 \mu \mathrm{m}(0.001 \mathrm{in}$.$) , therefore it is not con-$ sidered to be of any consequence. The dose contribution of the betas and gammas from the ${ }^{222} \mathrm{Rn}$ daughters is about $20 \%$ of these values (estimated from the $Q$ values) and is predominantly from the betas (see previous subsection). The mean beta energy is $1.0 \mathrm{MeV}$ which is a range of about $0.1 \mathrm{in}$. in asphalt and, therefore, irradiates a substantial fraction of a $1 / 4$ in. asphalt covering. 
Although a more rigorous treatment of the dose to tailings coverings could have been pursued, the treatment is sufficiently rigorous to permit upper bound estimates of this dose. Interpreting these values is yet another task. Almost all of this dose is from high LET and other low penetrating radiations. It is not considered to be of consequence to breaching or lowering the integrity of an asphalt emulsion covering, except in the unlikely event that radon gas would concentrate just under a thin covering. The gamma dose would be of consequence, but since this is so low (on the order of $10 \mathrm{rads} / \mathrm{yr}$ ) damage to the covering from other causes (weather, e.g.) would be a far more probable occurrence.

\section{ULTRA VIOLET EFFECTS}

Asphalt emulsion exposed to ultra violet radiation is known to degrade and form surface cracks but the degradation mechanism is not understood. Galloway ${ }^{(55)}$ described mechanical property change in asphalt concrete highway test plots as a function of the solar angle of incidence. Changes were evident with a 1-yr exposure and pronounced in a 2-yr exposure.

A test by the U.S. Water Conservation Laboratory of Arizona to catch precipitation involved covering the catchment areas with four types of water impervious coatings: 1) 1.5-mil black polyethylene film bonded to the soil with asphalt, 2) chopped fiberglass bonded to the soil with asphalt, 3) 1-mil aluminum foil bonded to the fiberglass with asphalt, and 4) 1-mil aluminum foil bonded to the soil with asphalt, and asphalt coating. Within 3 months exposure the asphalt coating developed cracks and was badly deteriorated in $1 \mathrm{yr}$ and the polyethylene-asphalt system was also badly deteriorated in $1 \mathrm{yr}$. Those plots covered with aluminum foil demonstrated excellent stability after $1 \mathrm{yr}$. It was assumed the asphalt and polyethylene-asphalt systems were degraded primarily by the ultraviolet exposure although heatup of the black polyethylene may have been a degradation contributor of that system.

Nearly always associated with ultraviolet exposure is oxygen and sometimes ozone, both known degraders of asphalt. The combination of 
ultraviolet and oxygen exposures results in the most rapid deterioration of asphalt films whereas shielding or reflecting these rays greatly enhances film longevity. An economical shield is a thin covering of soil, but is subject to wind erosion. An economical reflector is aluminum foil or a thin cover of fine aggregate high in ultra violet reflective wind erosion capability.

\section{THE CYCLIC FREEZE/THAW}

Freeze/thaw exposure of asphaltic concrete results in debonding the asphalt from the aggregate. This process, known as "stripping" in highway technology, is probably responsible for more Northern United States asphalt concrete highway deterioration than any other factor. ${ }^{(56)}$ According to Fromm, ${ }^{(57)}$ the initial phase of the stripping process was asphalt emulsification at the asphalt binder-aggregate interface. By precoating with cationic asphalt emulsion, then following this by the normal hot asphalt binder, the stripping problem was eliminated or drastically reduced, utilizing three problem aggregates. ${ }^{(58)}$ Arizona has installed test plots utilizing the emulsion precoating advantage on normally unsuitable absorptive aggregates which are quite susceptive to cyclic freeze-thaw damage. (59)

When charged asphalt emulsions (cationic and anion) are placed in contact with oppositely charged surfaces, the asphalt begins to absorb immediately. Since the affinity of an aggregate for ions is stronger than water, the water is displaced and the emulsion is destroyed. Asphalt films deposited in this manner, whether integral or not, are extremely difficult to remove by water addition. In this state, the asphalt film is not susceptible to freeze-thaw damage. The asphalt emulsion itself is very susceptible to freeze damage and this must be considered during storage or application.

MICROBIAL ATTACK

Microorganisms capable of attacking asphalt are very common in nature and can attack in either aerobic or anaerobic conditions. These organisms 
consist of bacteria and fungi. The bacterial organisms are members of the generia Psendomonas, Achromobactes, Micrococcus, Flavobacterium, Bacillus, Corynebacterium, Alcaligenes, Mycabacterium, and Nocardia. ${ }^{(60,61)}$ Some fungi including molds and yeast have been found capable of attacking asphalts. The microorganisms degrade the asphalt by consuming the lower molecular weight constituents which tend to give the asphalt its plastic characteristics. With them gone, the asphalt becomes brittle and cracks which opens up new surfaces to be attacked.

The environment has to be favorable to permit extensive damage to the asphalt. The bacteria enjoy a warm damp environment where the $\mathrm{pH}$ of the medium is about 7 , while fungi enjoy warm humid climates of a $\mathrm{pH}$ of about 4 . The number of microorganisms is greatly decreased by the improper environment. During the testing of canal liners under optimum growth conditions for bacteria only about a $1 \mathrm{mil}(0.025 \mathrm{~mm})$ thickness of asphalt was affected in 3 years.

The speed at which the microbes degrade the asphalt is very slow. It is so slow that the best protection against attack is to have a slightly thicker layer. The conditions have to be perfect for a great length of time to produce any noticeable damage. Therefore, the possibility of microorganisms destroying the asphalt emulsion seal is very small. An additional detriment to the degradation of the seal by bacteria is that the emulsifying agent is a bacterialcide. The agent tends to be the most concentrated on the surface of the layer where the bacteria would attack. This reduces the possibility of having the bacteria fail the seal.

\section{CHEMICAL ATTACK}

Asphalt emulsions are unstable in high and very low pH solutions. The $\mathrm{pH}$ limit of stability varies with emulsifier, asphalt particle size distribution, and the asphalt origin. A high salt content solution also destroys asphalt emulsions; the stability limits previously stated apply in addition to the variance of salt content and type. For most applications of asphalt emulsions these incompatible chemical environments are not present.

After deposition the asphalt film is capable of being chemically attacked, i.e., by reaction or solvent action. Asphalt can be hydrogenated 
to produce low-boiling hydrocarbons, but only elevated temperatures and pressures. 0xygen attacks asphalt resulting in production of water, but very little oxygen is attached to the asphalt. The process is much more pronounced at high temperatures and is used to produce a rubber-like material that is stable at elevated temperatures. At ambient temperatures the oxygen reaction is slow and probably influenced by ultraviolet radiation.

Other oxidants (i.e., nitric and sulfuric acids) result in water formation, but also form nitro and sulfo derivatives, respectively. There are many other oxidants which can be made to react with asphalt, but are not normally encountered in asphalt applications such as uranium tailings radon seals.

Strong alkalies react with saponifiable components of asphalt including acids, acid anhydrides, and ester linkages. Solvent action probably represents the greatest chemical attack potential for destroying asphalt seals. Aliphatic and aromatic hydrocarbons each will dissolve a portion of asphalt; a combination will solubilize a major portion of asphalt films. Solvent combinations (such as ethyl ether and aniline or petroleum naptha and benzl acetate) completely dissolve asphalt except occluded mineral matter. (63) Solvent combinations such as these would not be expected at uranium tailing sites.

\section{PRESSURE DIFFERENTIAL EFFECTS}

Differential gas pressures across a uranium tailings radon seal normally would result from thermal and atmospheric pressure changes. These changes would be expected to be gradual in nature and of very low pressure differential. No measurement data were located which even approximated the uranium tailings seal situation.

Should a seal fail under the slight pressure differential, the expected radon release would involve approximately the proportion of the fissure area in comparison to the entire tailings area. Resealing would be expected of pliable asphalt emulsion seal when temperatures allow cold flow conditions. 


\section{MECHANICAL EFFECTS}

The greatest risk to a uranium tailings radon seal is mechanical puncture or tearing by vehicular, animal, or personnel traffic. Thin asphalt film-compacted soil strengths are available through the highway medium, but data for the over non-compacted tailings situation is apparentl! nonexistent. Cover soil depth requirements for plastic pond liners would provide an estimation of soil depths to support expected traffic load. Some type of soil or aggregate cover will be required simply to eliminate the tacky adherence of dried asphalt emulsion to traffic of any type or load. Mechanical strength and soil overlay requirements involving uranium tailings radon seals should be determined through research effort. 


\section{APPLICATION OF ASPHALT EMULSION FOR SEALING TAILINGS}

Asphalt usage in the U.S. continues to grow each year, averaging a 3 to $5 \%$ increase/yr. The total asphalt usage in 1975 was 25.5 million tons with emulsified asphalt products totaling 5 million tons. These products were primarily intended for highway and roofing usage though considerable amounts of specialty products such as coatings were produced.

\section{APPLICATION METHODS}

The application methods for asphalt emulsion products vary considerably. Those of interest for sealing the uranium tailings include gravity pour, pump pressure spray, and possibly pneumatic placement.

The method commonly used in highway construction, to form roadbed subgrade water barriers, is gravity flow spreading. The thickness of the layer is controlled by the vehicle velocity, the viscosity of the asphalt emulsion, and the valve and orifice settings. Generally, roadbed water barrier installations involve a low zeta potential cationic asphalt emulsion of above average viscosity. This provides maximum penetration before setting (emulsion separation) and minimum run-off from irregular terrain. A typical emulsion of this type is Armak Company Redicote ${ }^{\circledR} E-63$. This material can be applied by any conventional method. The gravity flow dispensing method and the spray application method appear the most attractive method for applying the asphalt emulsion to the tailing piles.

In laboratory tests all radon seal specimens were prepared by pouring the Redicote ${ }^{\circledR} E-63$ over the tamped tailings sample. This avoids bubble formation, which could lead to the formation of pinholes upon setting. These conditions are believed to exist in the field application of this emulsion, but to our knowledge no one has been concerned with the possible formation of pinholes in the asphalt emulsion layer.

Spray application by pump pressurization is a promising method from the standpoint of material savings, manpower requirements, and steep slope installation problems. Conventional air pressure spray equipment, however, 
would entrain sufficient air, thus causing bubble formation and producing an intolerable numbers of pinholes in the coating. Some care is required when selecting a pump for cationic asphalt emulsion transfer since adherence to oxide and other surfaces having different charges than the emulsion can result in pumping shear force requirements exceeding the pump's capability which can cause subsequent plugging. Adequate pumping equipment for the pressurized transfer of the asphalt emulsion is an on-the-shelf item.

Optimum Thickness

Optimum sealing material thickness is expected to vary with the type of sealing material used. For example, uranium mine, surface radon, sealing materials studied by Hammon et al. ${ }^{(64)}$ are nonreactive with ore surfaces and would not be expected to penetrate the ore. Instead, adherence is by clinging to an irregular surface. Coating thicknesses vary with the amount of flow occurring before setting, but they probably average between 0.1 to $0.3 \mathrm{~mm}$. Tailings with a density much less than the original ore penetration is expected to be greater, possibly to the point where thicker films are required to effectively seal the radon.

Cationic asphalt emulsions react electrostatically with the uranium tailings so that thickness can be readily controlled. The zeta potential may be varied from 0 to $+120 \mathrm{MV}$. As the zeta potential is increased the electrostatic field is increased which results in more rapid attachment of the asphalt particulates. This, in turn, results in hydrophobic sealing and stops further penetration. The addition of asphalt emulsion to dry tailings results in emulsion separation and subsequent hydrophobic sealing prevents further penetration. Therefore, penetration can be controlled by controlling the tailings moisture and by selecting an emulsion of a specific zeta potential. If desired, additional penetration can be obtained by diluting the cationic asphalt emulsion with water or zero zeta potential asphalt emulsion.

The optimum or minimum thickness of asphalt emulsion applied to uranium tailings to effectively seal radon was not determined in this program. Asphalt emulsion-tailings seals, approximately 3 -mm thick, prevented 
sufficient radon diffusion to detect above the seal with radon under 0.014 to $0.021 \mathrm{~kg} / \mathrm{cm}^{2}(0.2$ to $0.3 \mathrm{psi})$. Attempts to form asphalt emulsion-tailings seals less than $3-\mathrm{mm}$ thick by gravity flow application were unsuccessful because of inadequate coverage. By dissolving the asphalt from a known area of a 3-mm thick seal and by measuring the volume of residual tailings, the calculated thickness of asphalt top cover was $11 \mathrm{~mm}$ or $37 \%$ of the composite seal thickness.

To determine the minimum thickness for asphalt emulsion-tailings seals, a pump pressure spray application would be required. Although program schedule and objectives precluded an investigation of this nature, it certainly is warranted in the interest of material costs and petroleum product conservation. The $3-\mathrm{mm}$ thick asphalt emulsion-tailings seals calculates to a $0.21 \mathrm{~m}^{2} / \mathrm{l}\left(8.4 \mathrm{ft}^{2} / \mathrm{gal}\right)$ coverage or approximately $38 \phi / \mathrm{m}^{2}\left(3.5 \phi / \mathrm{ft}^{2}\right)$ material cost based upon a price of $7.9 \phi / \ell(30 \$ / g a l)$. If pump pressure spray application is feasible, the material costs could be expected to be lowered substantially, provided tailings pile surfaces are not too irregular. The number of pinholes and other holidays produced which affect the radon release rate increases by applying a thinner seal thickness which reduces material costs. It must be decided how thin a seal can be made that is still within environmental limits. 


\section{LABORATORY EXPERIMENTAL WORK}

During 5 months of experimental work, 12 tests were conducted on radon diffusion and 2 tests were conducted on radium permeation. The test apparatus, procedures, and results are described in the following subsections.

\section{APPARATUS}

The basic experimental setup for asphalt emulsion tailings seai radon diffusion tests is shown in Figure 2 while photographs of the test apparatus are shown in Figures 3 through 7 . The test apparatus for the radon diffusion tests and the radium permeation tests was similar. The radium source was also used for the radon source and the same measurement system was used for both sets of tests. The radon diffusion test cell, however, did differ from the radium permeation cell.

\section{Radon Source}

A radium source was borrowed from an ongoing ERDA-sponsored program at PNL. This small radium source was borrowed to provide a radon source of sufficient size to evaluate asphalt emulsion-tailings radon seals and also to provide a $\mathrm{RaCl}_{2}$ solution to test asphalt emulsion-soil radium seals (Figure 4). By borrowing the $120-\mathrm{mCi}$ source, we estimated that at least $\$ 4,000$ and 6 months were saved.

The $500 \mathrm{~cm}^{3}, 0.5 \mathrm{~N} \mathrm{HCL}, 120 \mathrm{mCi}^{226} \mathrm{Ra} \mathrm{Cl}_{2}$ source was placed in a gas wash bottle train to extract dry, nonacidic ${ }^{222} \mathrm{Rn}$. The inlet bottle ( $A$ on Figure 2) contained sacrificial $0.5 \mathrm{~N} \mathrm{HCl}$, bottle $B$ was for safety overflow or backflow conditions, bottle $C$ contained the ${ }^{226} \mathrm{Ra} \mathrm{Cl}$, bottle $\mathrm{D}$ was again for safety overflow or backflow conditions, and bottle $E$ was a tandem soda lime-hydrove $\mathrm{CaSO}_{4}$. A pressure-vacuum gauge connected between bottles $C$ and $D$ indicated internal pressure conditions. The radon carrier was $150 \mathrm{~cm}^{3} / \mathrm{min}$ water-pumped nitrogen which was pressure-regulated through tandem regulators to obviate over-pressurization of the $\mathrm{RaCl}_{2}$. Entrance and exit flow meters controlled the nitrogen-radon mixture to $150 \pm 5 \mathrm{~cm}^{3}$ / min rate. 


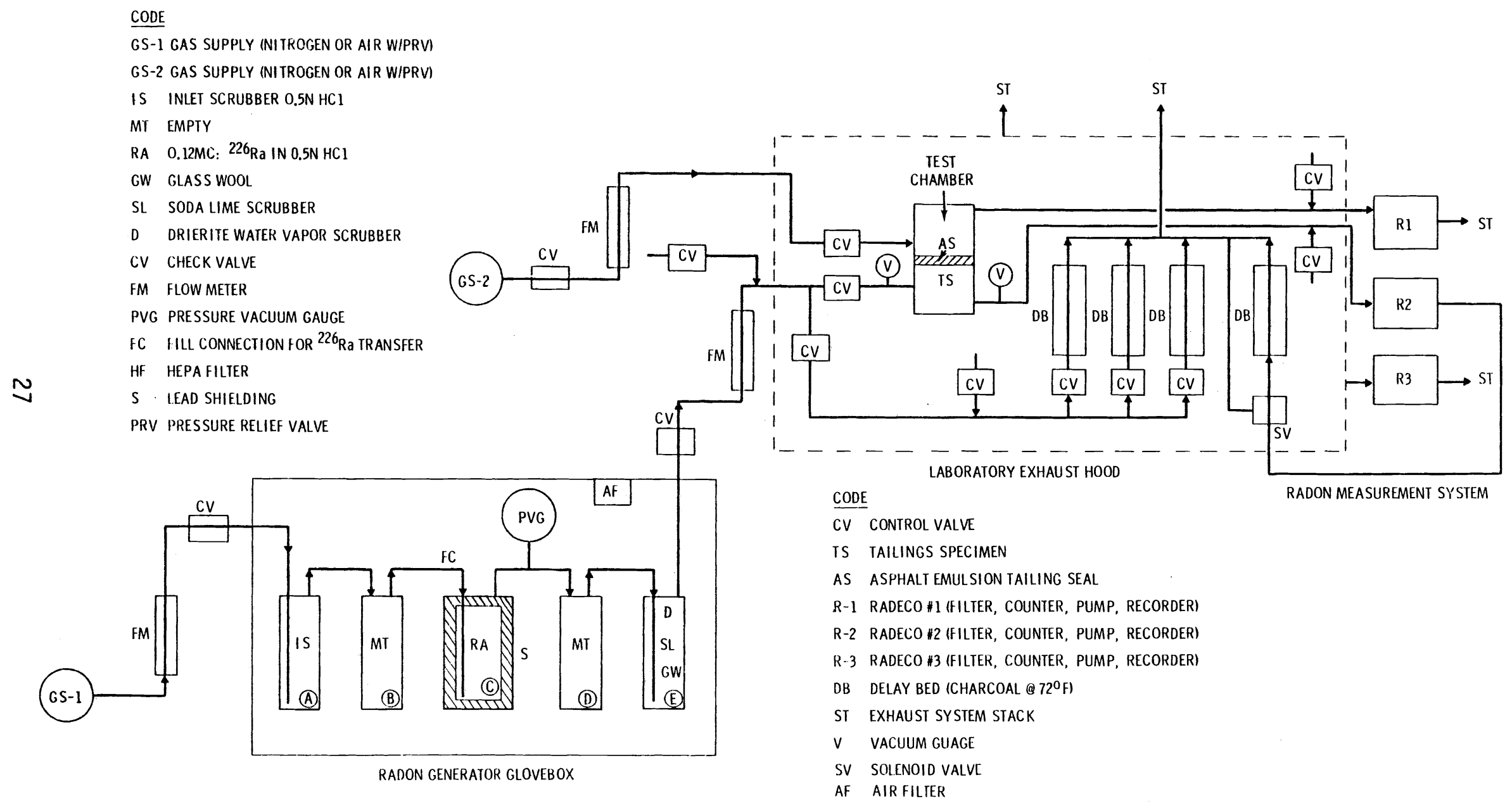

FIGURE 2. Basic Experimental Setup for Asphalt Emulsion Tailing Seal Radon Diffusion Tests 


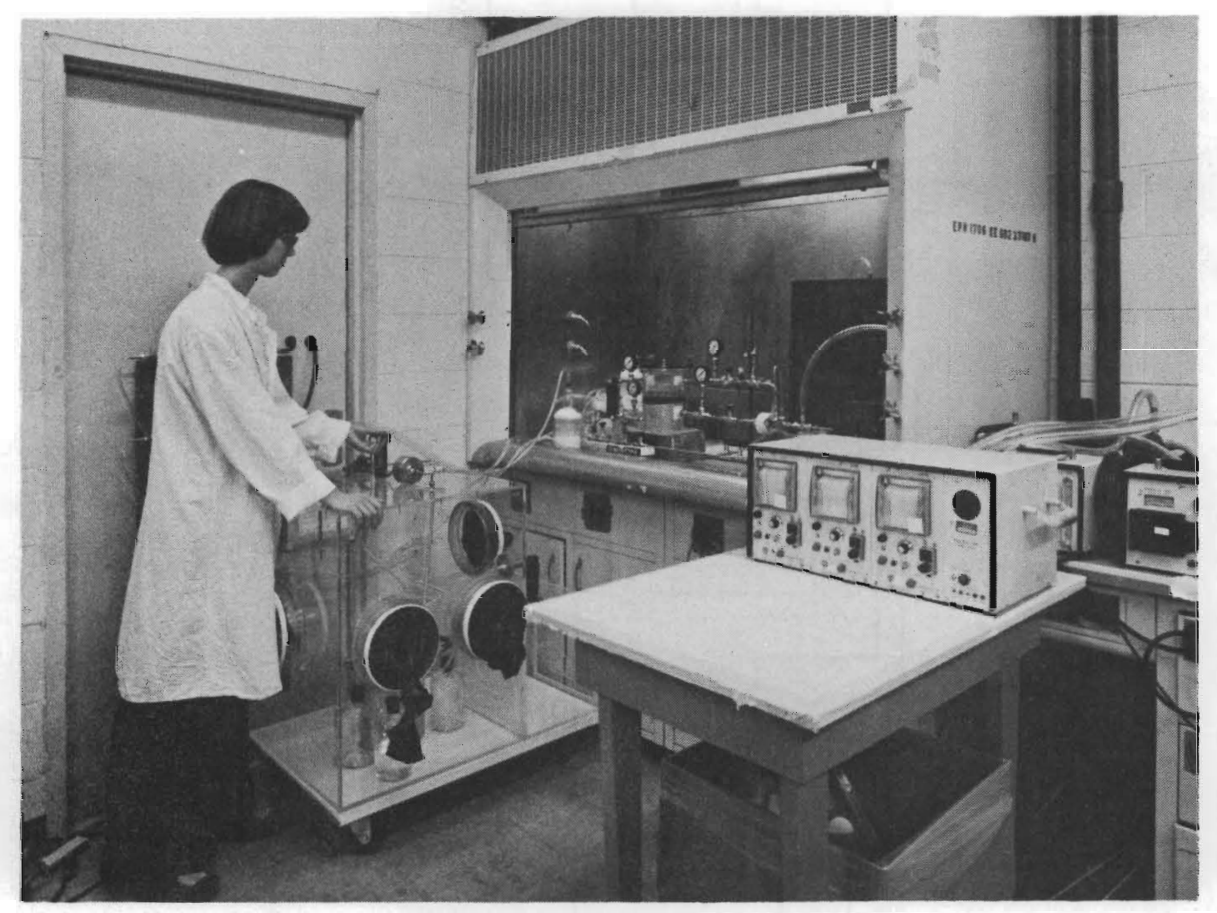

FIGURE 3. Overal1 View of Diffusion Test Apparatus

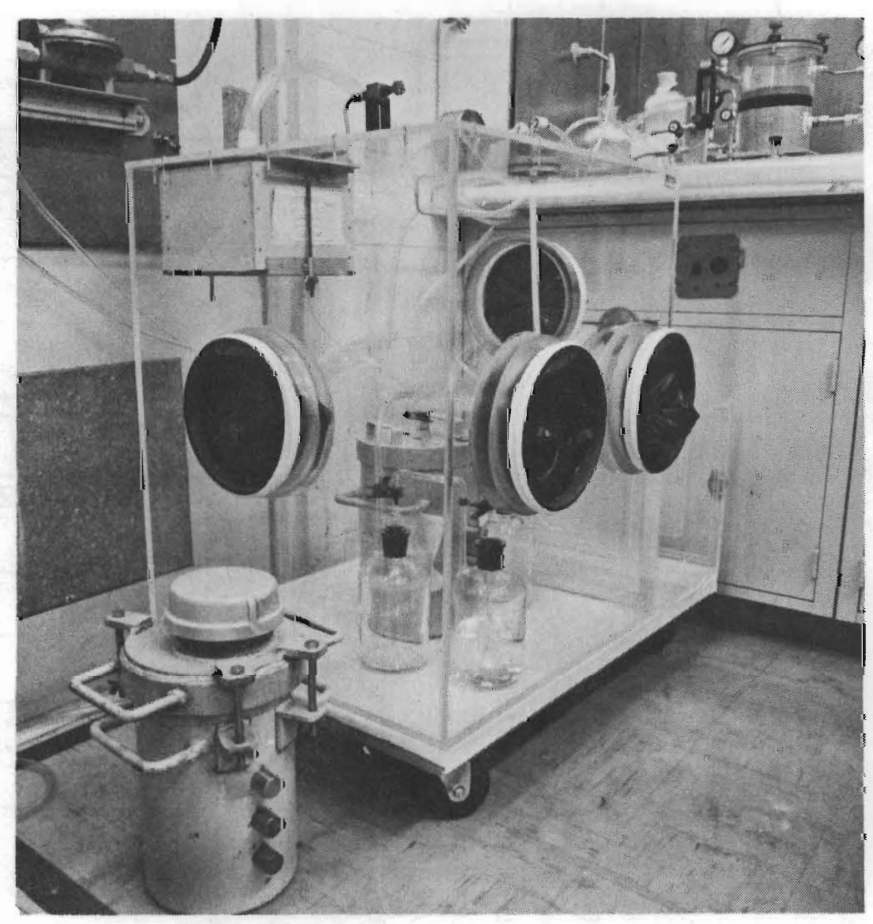

FIGURE 4. Radon Source 


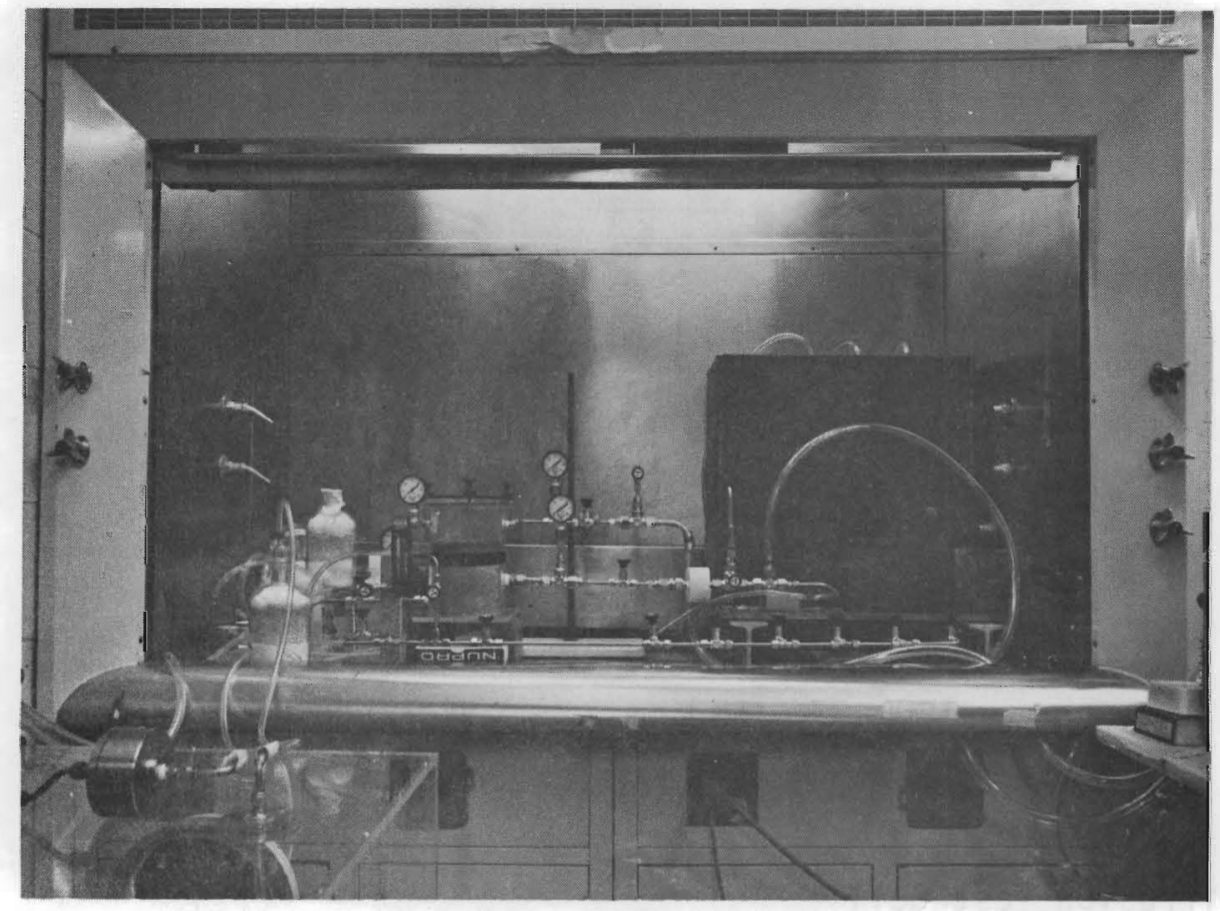

FIGURE 5. Radon Diffusion Test Cel1

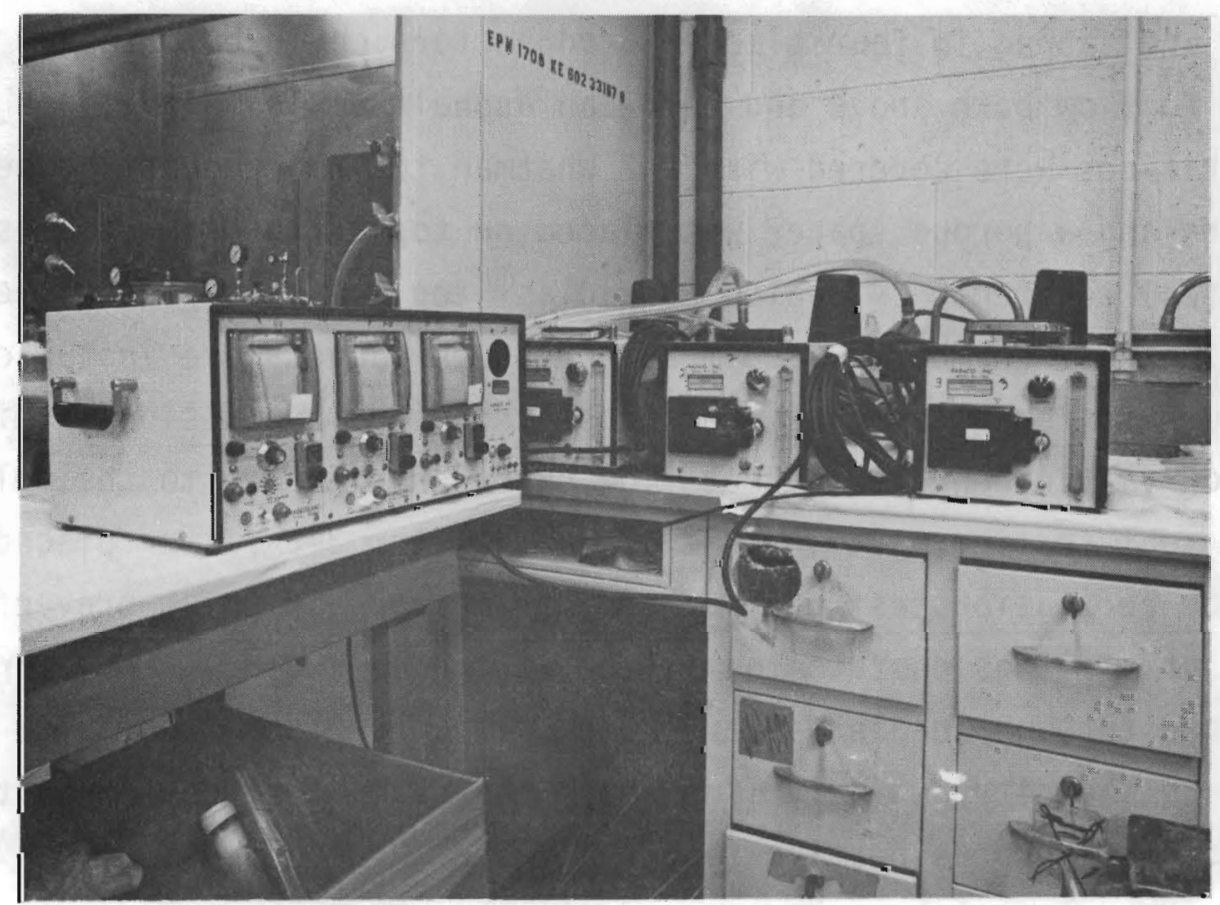

FIGURE 6. Radon Measurement System 


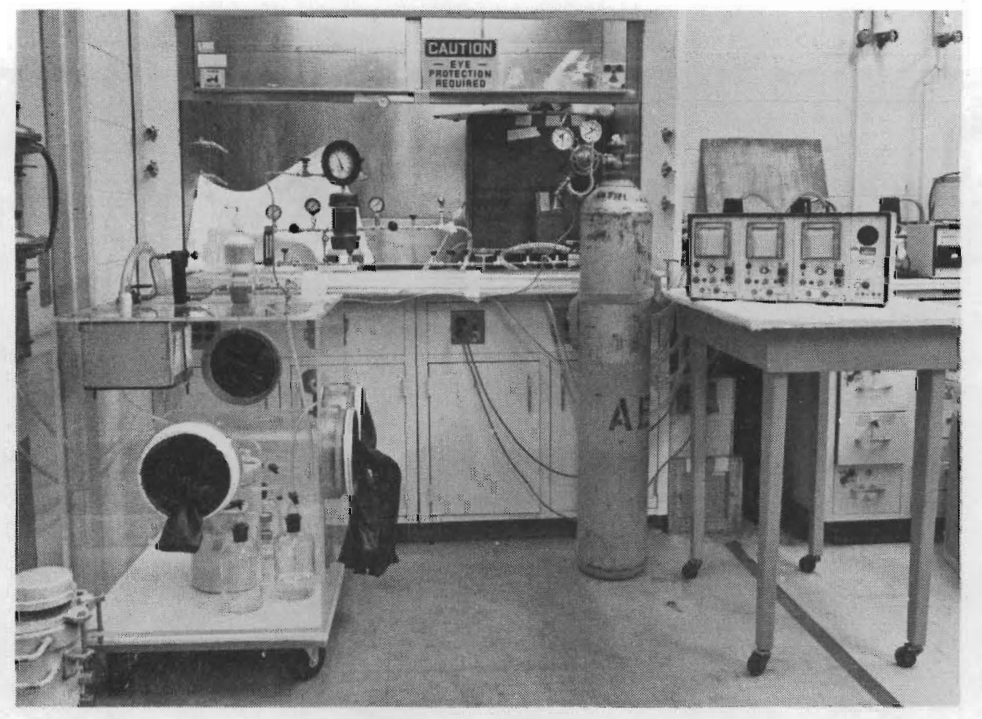

FIGURE 7. Radium Permeation Test Cell

\section{Radon Diffusion Test Cel1}

The radon diffusion test cell consisted of a polyacrylic (Plexiglas ${ }^{\circledR}$ ) cylinder with a sealed bottom Plexiglas plate (Figure 5). The cylinder was drilled and tapped in four places so connectors could be attached to enable the gas to flow both above and below an asphalt emulsion-tailings seal. These orifices were covered with \#42 Whatman to remove dust-ladened radon daughters and a porous spacer was placed on top of the seal to restrict upward seal movement. A sealed Plexiglas ${ }^{\circledR}$ top plate completed the radon permeation test chamber. Vacuum and pressure gauges were installed in-line to measure differential pressure across the asphalt emulsion-tailings seal. Diversion valving enabled direct flow of radon-nitrogen to the delay beds between seal testing. An in-line 47-mm diameter 3- $\mu$ filter placed between the radon permeation test chamber and the makeup air inlet prevented introduction of tailings dust to the filter at the detector. Laboratory air was introduced through needle valves in the nitrogen-radon line below the seal as well as the nitrogen-only line above the seal, and the composited gases flowed directly to respective filter-detector $\mathrm{RADeC}{ }^{\circledR}$ systems. 


\section{Radon Measurement System}

At the beginning of the program we decided that it was unnecessary to measure total radon either above or below the seal. Relative measurements of radon are quite satisfactory especially when all measurement systems are equivalent and are calibrated with the same radon source.

Three portable systems used at Hanford to measure airborne radiation were used with slight modifications to measure throughput radon levels (Figure 6). For asphalt emulsion-tailings radon seal experiments, one system monitored radon levels above the seal and one monitored them below the seal; the third system measured background radon levels in the laboratory. For the asphalt emulsion-soil radium seal experiments, one system monitored radon levels beneath the seal and one system measured laboratory air radon levels.

A radon measurement system consisted of the following components:

- Air pump (RADeCO Model VS-28)

- $0 i 1$ mist lubricated, requiring minimum $14 \mathrm{l} / \mathrm{min}(0.5 \mathrm{cfm})$ flow for motor cooling,

- Optimum flow 28 to $42 \mathrm{\ell} / \mathrm{min}$

- Detector-flowmeter RADeCO Model RD-300

- Scintillation detector system. Effective filter area $13.85 \mathrm{~cm}^{2}$ (2.15 in.2).

- Average filter pore size $3 \mu$. Flowmeter range 0 to $140 \mathrm{l} / \mathrm{min}$ (0 to $5 \mathrm{cfm}$ ).

- Power supply (RADeCO Model 440-MC)

- Discriminator-recorder (RADeCO Model 440-ME)

- Ranges 0 to 5,0 to 100,0 to 500,0 to $5000 \mathrm{cpm}$. Chart rate $2 \mathrm{~cm} / \mathrm{hr}$.

Radium Permeation Test Cell

The overall radium permeation test cell is shown in Figure 7 . A double capped $7.6 \mathrm{~cm}$ (3-in.) diameter Schedule $8015.2 \mathrm{~cm}$ (6-in.) long pipe nipple was modified to support a soil-asphalt emulsion seal under 
pressure supported by a porous media. The capped pipe nipple was drilled and tapped $180^{\circ}$ apart so fittings could be attached for a nitrogen flow-through carrier gas. The emanated ${ }^{222} \mathrm{Rn}$ from any ${ }^{226} \mathrm{RaCl}_{2}$ leakage would be transported to a RADeCO measurement system described in the previous subsection. The porous media consisted of $3-\mathrm{mm}$ diameter glass spheres with two layers of 16-mesh Fiberglas ${ }^{\circledR}$ screen (household fly screen) on top. A $6.4 \mathrm{~mm}$ (1/4-in.) layer of dry $+20-10$ mesh sand was placed on top of the bottom screen layer and an additional double layer of 16-mesh Fiberglas ${ }^{\circledR}$ screen covered the bottom sand layer. A loose-fitting Plexiglas ${ }^{\circledR} 6.4 \mathrm{~mm}$ (1/4-in.) thick disc was perforated with $3.2 \mathrm{~mm}$ (1/8-in.) drill holes to provide porous horizontal support. This disc was covered with four layers of 16 -mesh Fiberglas ${ }^{\circledR}$ screen followed by a $6.4 \mathrm{~mm}$ (1/4-in.) thick layer of dry $+20-10$ mesh sand. The soil sample was then placed on top and the highly permeable bed was compressed to relieve voids and for compacting purposes.

An attempt to use 50- and 100-mesh 304 stainless steel (SS) screens in place of Fiberglas ${ }^{\circledR}$ screen in early tests resulted in seal fractures and radium leakage. This apparently was caused by the spring action of the stainless steel screens after relieving the leak test pressure. No problems were encountered using the Fiberglas ${ }^{\circledR}$ screens even with five repeated $5.3 \mathrm{~kg} / \mathrm{cm}^{2}$ (75 psi) nitrogen compression/relieving leak tests.

\section{PROCEDURES}

\section{Radon Diffusion Seal Preparation and Installation}

The tailings sample was dried at $100^{\circ} \mathrm{C}$ until constant weight was achieved. The cooled tailings specimen was placed into the Plexiglas ${ }^{\circledR}$ radon diffusion test chamber (Figure 8) and tamped with 1.4 to $1.8 \mathrm{~kg} / \mathrm{cm}^{2}$ (20 to $25 \mathrm{psi}$ ) force to prevent void formation. Next, the specimen was sprayed with water until the surface appeared to be near saturation. A 5-min period allowed water penetration prior to adding the asphalt emulsion. After the water was added, a 3.2-mm thick surface layer was measured which contained a total water content of 13\% for Vitro specimens and 17 wt\% for UNI specimens. Then, $65 \mathrm{~cm}^{3}$ of asphalt emulsions was poured over the 


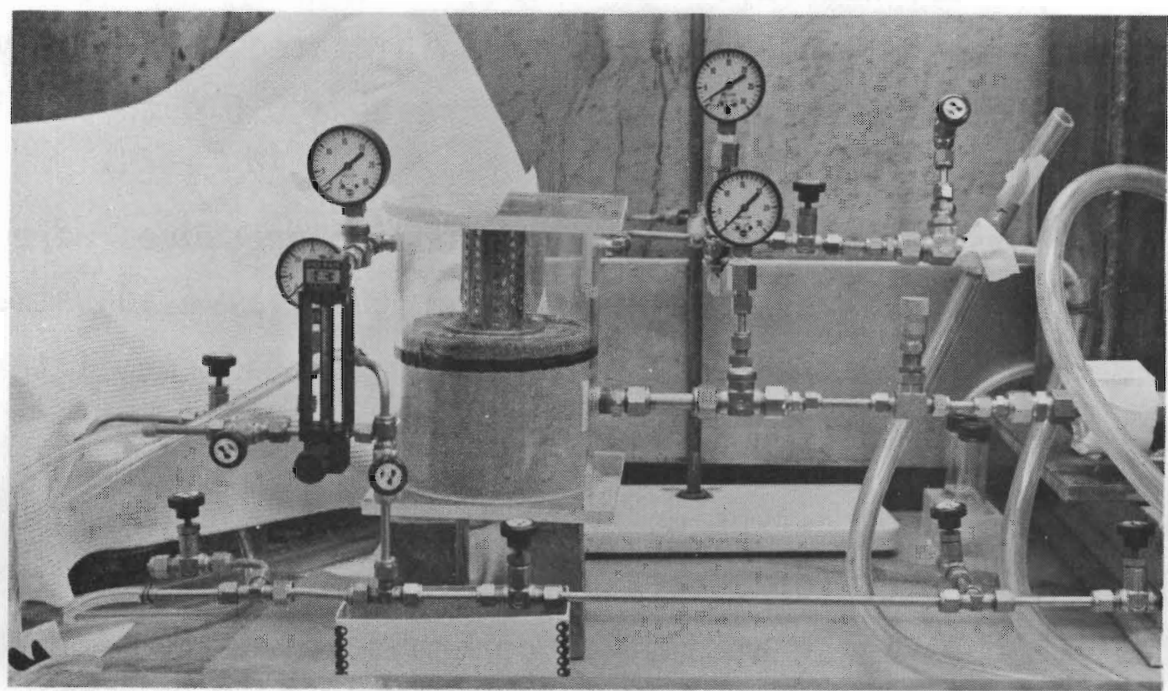

FIGURE 8. Radon Diffusion Test Chamber

surface and the chamber was tilted as necessary to ensure that the asphalt emulsion came in contact with the diffusion test chamber sidewalls. The estimated amount of asphalt emulsion above and within the tailings specimens was 50 to $55 \mathrm{~cm}^{3}$ for a $153.2 \mathrm{~cm}^{2}$ (23.75 in. ${ }^{2}$ ) specimen area. The specimen was then left for $24 \mathrm{hr}$ to allow for maximum asphalt emulsion penetration and curing. A $1.91 \mathrm{~cm}$ (3/4-in.) thick layer of dry $+20-10$ mesh sand was then placed over the asphalt emulsion-tailings layer to provide a radonporous media. The sand was tamped and leveled as was done with the tailings specimen previously described. A disc of 50 -mesh SS screen then covered the sand. A spool-shaped spacer fabricated from Plexiglas ${ }^{\circledR}$ tubing and sheet was used to support the top layer of sand and asphalt emulsion during pressure tests. The bottom sheet was perforated with multiple 1/8-in. drilled holes to allow radon permeation. The top plate of the radon diffusion test chamber was attached and sealed.

The radon diffusion test chamber was connected into the radon flow manifold for testing and new filters were installed at all detector heads. A11 pumps were started, and makeup air inlets were adjusted or adjustments were made at the detector flowmeter to regulate a precise $42 \mathrm{l} / \mathrm{min}$ ( $1.5 \mathrm{cfm}$ ) 
throughput. The $150 \mathrm{~cm}^{3} / \mathrm{min}$ nitrogen-radon mixture flow beneath the asphalt emulsion-tailings seal was initiated. The $150 \mathrm{~cm}^{3} /$ min nitrogen flow above the asphalt emulsion-tailings seal was then initiated. In-line valves both above and below the seal were adjusted to create a 0.014 to $0.021 \mathrm{~kg} / \mathrm{cm}^{2}$ ( 0.2 to $0.3 \mathrm{psi}$ ) positive nitrogen-radon pressure across the asphalt emulsiontailings seal. Desired equilibrated differential pressures were usualiy obtained with $1 \mathrm{hr}$ of valve adjustments. Periodic valve adjustments were necessary to maintain $42 \mathrm{l} / \mathrm{min}(1.5 \mathrm{cfm})$ throughput as the filters collected dust resulting in a pressure drop across the filter.

Normally, the radon diffusion tests involving asphalt emulsion-tailings seals would be conducted for 3 to 4 days, or to failure. One test was extended to 17.8 days in an attempt to determine the diffusion rate of radon through a $32-\mathrm{mm}(1 / 8-i n$.$) thick asphalt emulsion-tailings seal. Test data$ was recorded twice daily including:

- inlet pressure above seal

- outlet pressure above seal

- inlet pressure below seal

- outlet pressure below seal

- nitrogen flowrate above seal

- nitrogen flowrate below seal

- gas flowrate through three detector filters

Radiation $(\gamma)$ levels were measured at:

- work area background

- radon generator glove box

- seal chamber above seal

- seal chamber below seal

- Drierite ${ }^{\circledR}$ - soda lime bed

- radon delay beds

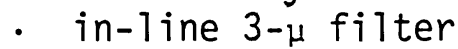

In addition, an alpha survey was conducted covering the entire test system at the beginning of each test and periodically throughout the test.

Radium Seal Test Procedure

The tailings sample was prepared in a similar manner to that for the radon diffusion tests; the radium permeability test chamber is shown in Figure 9. After seal preparation the top pipe cap was installed and a 


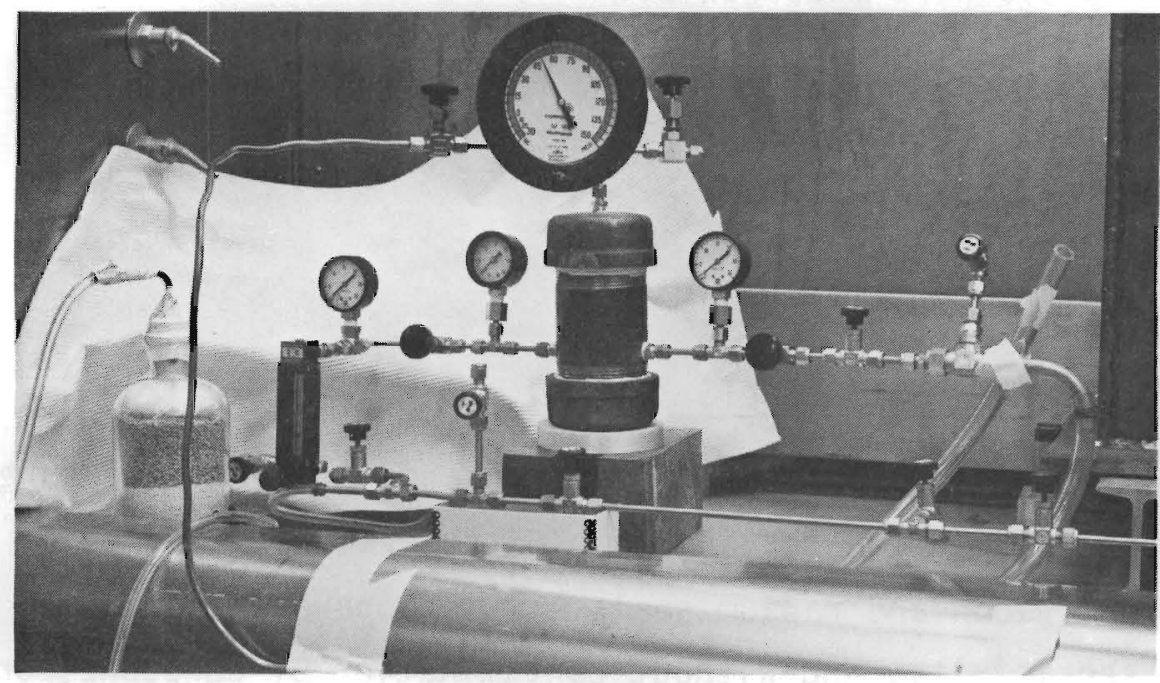

FIGURE 9. Radium Permeability Test Chamber

coating of epoxy was applied externally to both pipe-cap interfaces. After curing, one chamber penetration beneath the seal was capped and a pressure guage was attached to the other chamber. Nitrogen was introduced until $5.3 \mathrm{~kg} / \mathrm{cm}^{2}$ (75 psi) was reached. After temperature equilibration pressure above and below the seal was monitored periodically. If no leakage was observed over $24 \mathrm{hr}$, the pressure was relieved and the chamber was installed into the radon measurement system. A Swagelock ${ }^{\circledR}$ cap vertically penetrating the top pipe cap was opened and $23 \mathrm{ml}$ of $0.25 \mathrm{~N} \mathrm{HCl}$ containing $240 . \mu \mathrm{Ci}$ ${ }^{226} \mathrm{Ra}$ was transferred by syringe to the top surface of the asphalt emulsionsoil seal. The cap was then replaced and a $150-\mathrm{cm}^{3} / \mathrm{min}$ nitrogen flow was initiated beneath the asphalt emulsion-soil seal. Makeup laboratory air was valved in to provide $42 \mathrm{l} / \mathrm{min}(1.5 \mathrm{cfm})$ detector filter throughput. Two other measurements (one for redundancy) also measured the radon content of the laboratory air at $42 \mathrm{l} / \mathrm{min}(1.5 \mathrm{cfm})$ throughput. Test data was recorded twice daily including:

- pressure above $\mathrm{RaCl}_{2}$

- nitrogen flowrate below seal

- gas flowrate through three detector filters 
Radiation $(\gamma)$ levels were measured at:

- work area background

- radon generator glove box

- seal chamber

- Drierite - soda lime bed

- radon delay beds

\section{RADON AND RADIUM SEAL TEST RESULTS}

The radon generator, permeation testing apparatus, and measurement systems provided a complete testing complex to evaluate the use of asphalt emulsion to form radon and radium seals. This apparatus performed with reliability, sensitivity, and without contamination of personnel or costiy equipment.

The radon permeation tests demonstrated the following:

- Cationic asphalt emulsion is a feasible radon seal material at higherthan-expected radon pressures.

- Radon permeation through 3.2-mm (1/8-in.) thick asphalt emulsiontailings seal was not measurable.

- The minimum thickness of Armak E-63 emulsion-tailings seal to prevent radon diffusion is less than $3.2 \mathrm{~mm}$ (1/8-in.).

- The asphalt emulsion must not be agitated to form a foam layer which is then applied to the tailings.

- Sufficient tailings surface water content is essential to achieve emulsion penetration.

- Irradiation of asphalt emulsion-tailings seals to $10^{5} \mathrm{R}$ level does not affect seal integrity.

- Cyclic freeze/thaw of asphalt emulsion-tailings does not appear to affect radon seal integrity.

- At least two types of cationic asphalt emulsions (Armak E-63 and Armak 13MR) form radon seals with Vitro (Salt Lake City) and UNI (Ambrosia Lake, New Mexico) tailings. 
The pressurized radium retention test demonstrated the following:

- $\mathrm{RaCl}_{2}$ in $0.5 \mathrm{~N} \mathrm{HCl}$ at $3.6 \mathrm{~kg} / \mathrm{cm}^{2}$ (50 psi) can be retained by $6.4 \mathrm{~mm}$ (1/4-in.) thick Armak E-63 emulsion-Vitro tailings seal.

- A 6.4-mm (1/4-in.) thick Armak E-63 emulsion-Vitro tailings seal is also capable of containing radon and nitrogen at $3.6 \mathrm{~kg} / \mathrm{cm}^{2}$ (50 psi).

The radon permeation tests and the radium retention test are discussed in more detail in the following subsections.

Radon Diffusion Tests

A total of seven radon diffusion tests were conducted during this program. Table 13 lists the variables for each test and or test phase.

\section{TABLE 13. Radon Diffusion Test Conditions}

\begin{tabular}{|c|c|c|c|c|c|c|c|}
\hline \multirow{2}{*}{$\begin{array}{c}\text { Test } \\
\text { Number }\end{array}$} & \multicolumn{2}{|c|}{$\begin{array}{c}\text { Seal } \\
\text { Thickness } \\
\end{array}$} & \multirow{2}{*}{$\begin{array}{l}\text { Seal Composition } \\
\text { (Armak E-63 } \\
\text { Emuls son-Tailings) } \\
\text { Sample Number } \\
\end{array}$} & \multicolumn{2}{|c|}{ Differential Seal Pressure } & \multicolumn{2}{|c|}{$\begin{array}{c}\text { Exposure } \\
\text { Time }\end{array}$} \\
\hline & $\mathrm{Im}$ & in. & & $\mathrm{kg} / \mathrm{cm}^{2}$ & psi & hr & days \\
\hline Test 2 & 19.1 & $3 / 4$ & SS-1 & $7 \times 10^{-3}-2.1 \times 10^{-2}$ & $0.1-0.3$ & 192 & 8.2 \\
\hline $\begin{array}{l}\text { Test } 3 \\
\text { Phase I }\end{array}$ & 3.2 & $1 / 8$ & SS-1 & $\begin{aligned} 7 \times 10^{-3} & -7 \times 10^{-2} \\
& -2.1 \times 10^{-2}\end{aligned}$ & $\begin{array}{r}0.1-1.0 \\
-0.3\end{array}$ & 426 & 17.8 \\
\hline Phase II & 3.2 & $1 / 8$ & Irradiated SS-1 & $1.4 \times 10^{-2}-4.2 \times 10^{-2}$ & $0.2-0.6$ & 276 & 11.5 \\
\hline Phase III & 3.2 & $1 / 8$ & $\begin{array}{l}\text { Irradiated, Cycle } \\
\text { Freeze-Thaw SS-1 }\end{array}$ & $1.4 \times 10^{-2}-2.1 \times 10^{-2}$ & $0.2-0.3$ & 120 & 5 \\
\hline Test 4 & 3.2 & $1 / 8$ & SS-14 & $7 \times 10^{-3}-2.8 \times 10^{-2}$ & $0.1-0.4$ & 95.5 & 4 \\
\hline $\begin{array}{l}\text { Test } 5 \\
\text { Phase I }\end{array}$ & 3.2 & $1 / 8$ & SS-10 & $1.4 \times 10^{-2}-2.8 \times 10^{-2}$ & $0.2-0.4$ & 41.5 & 1.7 \\
\hline Phase II & 3.2 & $1 / 8$ & SS-10 & $7 \times 10^{-3}-2.1 \times 10^{-2}$ & $0.1-0.3$ & 74.3 & 3.2 \\
\hline Test 6 & 3.2 & $1 / 8$ & ALNM-14 & $7 \times 10^{-3}-2.1 \times 10^{-2}$ & $0.1-0.3$ & 144 & 6 \\
\hline Test 7 & 3.2 & $1 / 8$ & ALNM-15 & $1.4 \times 10^{-2}-4.2 \times 10^{-2}$ & $0.2-0.6$ & 91 & 3.8 \\
\hline
\end{tabular}

\section{Test 2}

This preliminary experiment was primarily designed to evaluate apparatus design and seal preparation procedures. A $19.2 \mathrm{~mm}$ (3/4 in.) thick Armak E-63 cationic asphalt emulsion tailings seal specimen was saturated with distilled water. This resulted in a large pressure drop in nitrogen-radon flow through the specimen placing a considerable pressure force upward on the bottom of the seal which caused considerable bulging. The test was abandoned when 
flow systems were initiated. Radon was not detected above the seal throughout this phase of the experiment.

\section{Test 4}

The SS-14 tailings specimen was tamped to compact it as were all specimens. To achieve total asphalt emulsion coverage no humus protrusions were allowed in the specimen although no humus was removed from the specimen. Radon was not detected above the seal throughout this experiment.

\section{Test 5 (Phase I)}

This specimen from the Vitro site consisted, at least in part, of a soil-gravel fill material which required that the layer surface aggregate be removed to achieve total asphalt emulsion coverage. The E-63 emulsion is normally stirred to ensure suspension prior to addition. But, in this experiment, the emulsion was inadvertently vigorously agitated (by shaking) resulting in the formation of a foam layer which surfaced as the emulsion was added to the tailings specimen. During seal formation, the foam layer remained on top where bubbles periodically collapsed. Although the seal surface appeared somewhat pock-marked, no penetrations were visible just prior to installation in the radon test apparatus. No radon was detected above the seal for 1.7 days of testing, but then the radon content rose rapidly. The test was discontinued and the test chamber removed and opened for examination. Since the location of the leak was undetectable either visually or with a portable alpha survey instrument, it was assumed that a very thin seal was formed after a bubble collapse. This thin seal was probably unable to withstand continuous 0.014 to $0.021 \mathrm{~kg} / \mathrm{cm}^{2}(0.2$ to $0.3 \mathrm{psi})$ stress and yielded after 1.7 days which allowed high-level radon penetration.

\section{Test 5 (Phase II)}

The failed seal from Phase I was cut out and removed along with any adhering tailings specimen. The tailings specimen was resurfaced and compacted, and asphalt emulsion (mixed by stirring) was added. This test seal chamber was connected into the radon flow system and both gas systems were initiated. Radon was not detected above the seal throughout this phase of the experiment. 


\section{Test 6}

When the cationic asphalt emulsion types E-63 and 13-MR were added to the compacted tailings specimen [from the United Nuclear Industries (UNI) site near Grants, New Mexico] a white, fluffy, crystalline material appeared on top of the seal. Another addition of asphalt emulsion(s) only resulted in repeated efflorescence. Although not quantitatively analyzed, the watersoluble salts effloresced when $0.5 \mathrm{~N} \mathrm{HCl}$ was added. This indicated the presence of carbonate/bicarbonate which was probably the result of the alkaline leach process used during uranium extraction.

The seal chamber was connected into the radon test system and the two gas flow systems were initiated. Radon was not detected above the seal throughout this experiment.

\section{Test 7}

Considerably more salt efflorescence appeared when the asphalt emulsion was added to the ANNM-15 specimen than with the ALNM-14 specimen. The seal chamber was connected into the radon test system and the two gas flow systems were initiated. Radon was not detected above the seal throughout this experiment.

A small laboratory experiment was also conducted to rid the tailings surfaces of efflorescing salts in the event of seal failure. Small quantities of $0.5 \mathrm{~N} \mathrm{H}_{2} \mathrm{SO}_{4}$ were added followed by water to remove from the surface what apparently was $\mathrm{CO}_{3}=\mathrm{HCO}_{3}=$. There was no visual efflorescence when asphalt emulsion was added at this point.

An alpha survey over the effloresced salts from a ALNM-15 tailingsArmak E-63 emulsion seal indicated that radium, thorium, or aphla emitting daughters were not present.

Radon seal tests were planned for Tests 8 through 19 on the tailings specimens 1 isted in Table 14. However, time did not permit 4-day tests on each of the specimens. Therefore, visually different tailings specimens were selected for testing from each site. For example, surface tailings specimens were taken from the Vitro site appeared to be processed 
tailings (SS-1), humus from sewage sludge, and processed vanadium tailings overburden (SS-14) while a soil-gravel overburden (SS-10) appeared visually to encompass all types of specimens present. At the UNI site all specimens appeared visually alike, but laboratory testing with Armak E-63 emulsion demonstrated that the greatest efflorescing occurred first in ALNM-15, then in ALNM-14. Since these specimens appeared to be the most difficult to seal, they were selected for testing.

TABLE 14. Planned Radon Seal Test Specimens

\begin{tabular}{cc}
$\begin{array}{c}\text { Test } \\
\text { Number }\end{array}$ & $\begin{array}{c}\text { Tailings } \\
\text { Specimen Numb }\end{array}$ \\
\cline { 2 - 3 } 8 & SS-3 \\
9 & SS-4 \\
10 & SS-5 \\
11 & SS-9 \\
12 & SS-12 \\
13 & SS-13 \\
14 & SS-101 \\
15 & ALNM-9 \\
16 & ALNM-10 \\
17 & ALNM-11 \\
18 & ALNM-12 \\
19 & ALNM-13
\end{tabular}

\section{Radium Seal}

Two radium seal tests were conducted during this program. The variables for these tests are listed in Table 15 and details of the tests are provided in the following subsections.

\section{TABLE 15. Radium Seal Test Results}

\begin{tabular}{|c|c|c|c|c|c|c|}
\hline \multirow{2}{*}{$\begin{array}{l}\text { Test } \\
\text { Number }\end{array}$} & \multicolumn{2}{|c|}{$\begin{array}{c}\text { Seal } \\
\text { Thickness }\end{array}$} & \multirow[t]{2}{*}{$\begin{array}{l}\text { Seal Composition } \\
\text { (Armak E-63 } \\
\text { Emulsion-Tailings) } \\
\text { Sample }\end{array}$} & \multirow{2}{*}{$\begin{array}{l}\text { Differential } \\
\text { Seal Pressure, psi }\end{array}$} & \multicolumn{2}{|c|}{$\begin{array}{l}\text { Exposure } \\
\text { Time }\end{array}$} \\
\hline & $\mathrm{mm}$ & in. & & & $\mathrm{hr}$ & days \\
\hline $\begin{array}{l}\text { Test } 1 \\
\text { Phase I }\end{array}$ & 64 & $1 / 4$ & $\begin{array}{l}\text { Subsoil from Vitro } \\
\text { Site }\end{array}$ & 50 & 408 & 17 \\
\hline Phase II & 64 & $1 / 4$ & $\begin{array}{l}\text { Subsoil from Vitro } \\
\text { Site }\end{array}$ & 0 & 144 & 21 \\
\hline
\end{tabular}




\section{Test 1 (Phase I)}

After exposing the seal to $5.4 \mathrm{~kg} / \mathrm{cm}^{2}$ (75 psi) nitrogen for $24 \mathrm{hr}$ with zero leakage, the test chamber was pressure-relieved and connected into the radon test system. A $150-\mathrm{cm}^{3} / \mathrm{min}$ nitrogen flow beneath the seal was initiated and a $25-\mathrm{cm}^{3} 0.5 \mathrm{~N} \mathrm{HCl}$ solution containing $240 \mu \mathrm{Ci}$ of ${ }^{226} \mathrm{Ra} \mathrm{Cl}_{2}$ was placed on top of the seal. A $3.6 \mathrm{~kg} / \mathrm{cm}^{2}$ (50 psi) nitrogen overpressure was then exerted on the $\mathrm{RaCl}_{2}$ solution. Radon was not detected below the seal during this experiment, and although radon diffusion was expected at 50 psi pressure, it was not detectable.

\section{Test 1 (Phase II)}

A second radium seal test apparatus was fabricated and filled to determine detectability of a solution leak. During sequential filling of the test apparatus with porous media, screens, and then the Vitro subsoil specimen, a 50- $\mu$ l (microliter) sample of the Phase $\mathrm{I} \mathrm{RaCl}_{2}$ test was introduced into the subsoil specimen prior to forming the subsoil-asphalt emulsion seal. Nitrogen overpressure was not needed in this test. Radon daughter buildup at the detector filter was observed shortly after the $150 \mathrm{~cm} / \mathrm{min}$ nitrogen flow was introduced. Daughter buildup-daughter decay equilibrium was achieved in $10 \mathrm{hr}$. Taking into account the natural radon background observed in the other two measurement systems at the same $1.5 \mathrm{cfm}$ throughput rate, a net radon increase of $110 \mathrm{c} / \mathrm{m}$ was detected above the other two systems. In the Phase I test a $\mathrm{RaCl}_{2}$ leak of about $25 \mu l$ would have been observable.

\section{Test 2}

A test was planned for the subsoil specimen obtained from the UNI site near Grants, New Mexico but insufficient time prevented this. A laboratory beaker test was conducted which involved mixing the UNI subsoil specimen and Armak E-63 emulsion. This test indicated that a sufficient cationic exchange capacity was available in the subsoil specimen to achieve at least a $\mathrm{RaCl}_{2}$ solution seal, even perhaps a gas-tight seal as that observed in Test 1 . 


\section{CONCLUSIONS}

On the basis of the experimental results from this program the following conclusions may be drawn.

- A $3.2 \mathrm{~mm}$ (1/8-in.) thick Armak E-63 cationic asphalt emulsion-tailings (Vitro-Salt Lake City or UNI-Ambrosia Lake) seal is very effective in preventing radon surface release to the environment. Probably, a seal much less than $3.2 \mathrm{~mm}(1 / 8-i n$.$) thick would also be very effective,$ but was not achievable with available equipment.

- The physico-chemical properties of tailings surface must be established to identify asphalt emulsion and or additive requirements to effect good radon seals.

- The tailings surface moisture content must be controlled to facilitate emulsion penetration, thus seal formation. The optimum tailings surface moisture level was not determined, but is believed to be near saturation.

- The mixing or application of asphalt emulsion to tailings must not result in foaming since coating pinholes may result.

- A $3.2 \mathrm{~mm}$ (1/8-in.) thick Armak E-63 cationic asphalt emulsion-Vitro tailings seal subjected to $10^{5} \mathrm{R}$ gamma exposure is very effective in preventing radon permeation at radon pressures up to 0.014 to $0.021 \mathrm{~kg} / \mathrm{cm}^{2}$ (0.2 to 0.3 psi).

- A 0 to $72^{\circ} \mathrm{F}$ cyclic freeze/thaw of a $3.2 \mathrm{~mm}$ (1/8-in.) thick Armak E-63 cationic asphalt emulsion-Vitro tailings seal did not affect the permeation seal capability of 0.014 to $0.021 \mathrm{~kg} / \mathrm{cm}^{2}(0.2$ to $0.3 \mathrm{psi})$ radon through 19 cycles.

- Two cationic asphalt emulsions (Armak E-63 and Armak 13-MR) appear usable to combine with Vitro and UNI tailings to form thin, effective radon diffusion barriers. Since the E-63 emulsion is considerably lower in cost, the majority of the experimental effort involved this readily available material. It is believed Armak E-63 or comparable product may well be the most cost-effective radon diffusion barrier material. 
- A $6.4 \mathrm{~mm}$ (1/4-in.) thick Armak E-63 cationic asphalt emulsion-Vitro subsoil seal was capable of preventing permeation of $\mathrm{RaCl}_{2}$ in $0.5 \mathrm{~N} \mathrm{HCl}$ solution, radon, and nitrogen under $3.6 \mathrm{~kg} / \mathrm{cm}^{2}$ (50 psi) overpressure for a 17-day period. It is not known how long permeation preventation could be extended or if thinner seals would be as effective. 


\section{DISCUSSION OF SEALING MECHANISM}

This program prompts the obvious question "Why do cationic asphalt emulsion-tailings seals provide considerably more effective radon and radium diffusion barriers than other materials?" The answer probably lies in the sealing mechanism.

Cationic asphalt emulsions consist of tiny, pliable droplets in water that are charged oppositely to the aggregates and fines of tailings. These droplets remain suspended in the water until encountering an oppositely charged field emanating from a surface (such as tailings aggregate). As the droplet approaches the aggregate surface electrostatic field, it begins to conform to the aggregate surface topography. This process continues until contact is made, then further droplet movements result in the droplet becoming flat which results in a thin film section that is electrostatically held in place. Total film coverage results as additional droplets are attracted into place. This process is illustrated in Figure 10. During the bonding process when cationic asphalt emulsion droplets are bonded to tailings aggregates, the intermediate water is expelled or trapped. If a film of water exists between the aggregate and emulsion, its thickness must be less than $3.5 \times 10^{-8} \mathrm{~cm}$ (diameter of nitrogen molecule. ${ }^{(65)}$ No difficulty was encountered in containing nitrogen at $3.6 \mathrm{~kg} / \mathrm{cm}^{2}$ (50 psi). Trapped or interstitial water films would be expected to decrease with time by evaporative or aggregate-absorption processes. Also, since the hydrophobic emulsion is attached electrostatically to the aggregate, water cannot enter at expected pressures and temperatures, thus preventing emulsionaggregate bond from opening and enabling radon diffusion. As long as the inplace asphalt emulsion droplet retains its charge or the asphalt is not degraded, the diffusion barrier should be integral. Obviously, if the aggregate size is progressively increased there becomes a point where total aggregate coverage does not seal inter-aggregate voids. No sealing problems are expected with tailings tested to date since they have'a sufficiently small size distribution. 

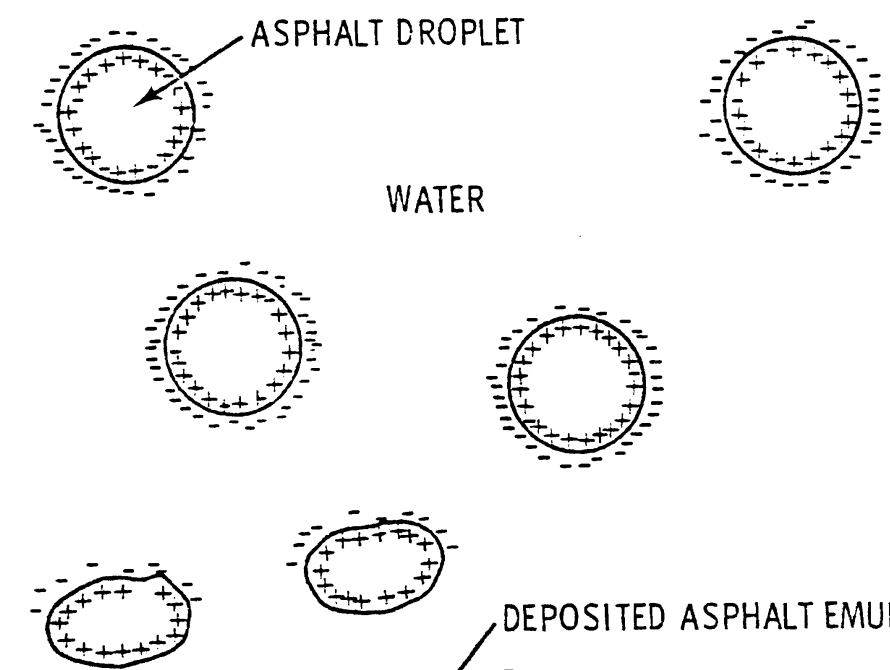

DEPOSITED ASPHALT EMULSION

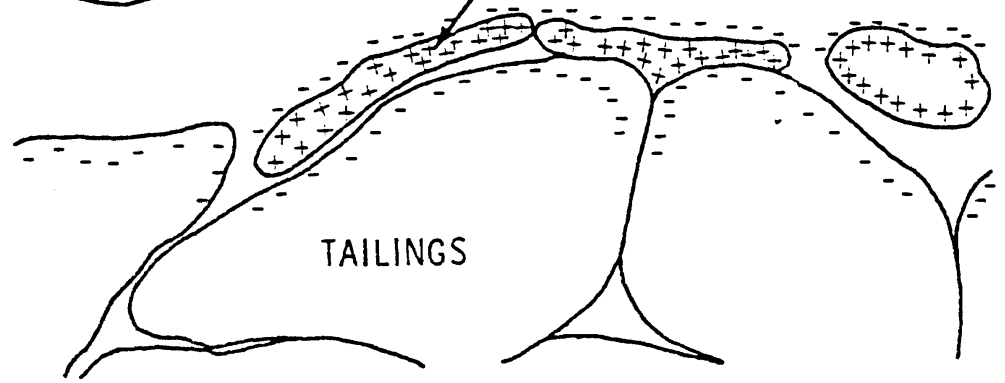

FIGURE 10. Cationic Asphalt Emulsion Deposition

Other organic coatings are based on an entirely different bonding system. Some systems attach themselves to the aggregate surface mechanically such as the polymer systems which include water-dispersed epoxy, catalyzed furfuryl alcohol, styrenated polyester, plasticized polyvinyl acetate latex, vinylidene chloride copolymer, acrylic emulsion, and others. No chemical or electrostatic bonding is involved with these systems. Consequently, water levels between aggregate and polymer are subject to change providing radon diffusion pathways. The radon diffusion barrier capability of these materials is the material itself, thus requiring that the total aggregate surface be covered resulting in an integral $\mathrm{film}$ requirement for maximum effectiveness.

Another reason may be given for the performance difference between cationic asphalt emulsion and the polymeric systems. If a coating material is of low viscosity and the tailings aggregates are sufficiently porous, a 
coherent film cannot be formed. This results in poor radon diffusion barriers as was evident in a uranium ore coating study. ${ }^{(66)}$ Immediately upon contacting oppositely-charged surfaces cationic asphalt emulsion deposits form hydrophobic barriers. This results in self-plugging which creates coherent films upon evaporation.

Another major performance difference in cationic asphalt emulsion and polymeric coatings involves coating flow when applied over irregular or sloped tailings surfaces. Polymeric coatings, which do not react with the tailings aggregate, will gravity flow to lower levels, congregate, and polymerize. The upper level tailings aggregate is left with far too little material to affect radon sealing and the aggregate in the bottom of the trench receives considerably more coating material than necessary.

Cationic asphalt emulsion reacts immediately with tailings aggregate, expelling carrier water from the emulsion as well as aggregate contained moisture. Tailings aggregate located on steep slopes and peaked mounds could be effectively covered with minimum excess of coating material because of the emulsion-aggregate reaction.

Other reasons may be given for performance differences such as polymeric coating shrinkage-crack formation, solvent evaporation or absorption resulting in incomplete coverage, or improper catalyst-polymer balance, and many others. The major reason for the observed performance difference is believed to be the bonding mechanism. Polymeric coatings are purely a mechanical bond whereas the cationic asphalt emulsion is an electrostatic bond. 


\section{RESEARCH RECOMMENDATIONS}

Laboratory testing has shown that potential radon diffusion barriers are feasible with application of low zeta potential cationic asphalt emulsion to Vitro and UNI tailings. A $3.2 \mathrm{~mm}(1 / 8-i n$.$) thick cationic asphalt emul-$ sion-tailings seal totally prevents radon diffusion; a $6.9 \mathrm{~mm}$ (1/4-in.) thick cationic asphalt emulsion-subsoil seal totally prevents radium elution. Additional laboratory and field work is needed before cationic asphalt emulsion is widely used. Although the research effort of this program was directed toward inactive uranium tailings piles, it is obviously applicable to active as well as planned operations. Additional research/development effort is needed in the following areas.

ADDITIONAL LABORATORY TESTING

The following areas should be further investigated:

- Only Vitro and UNI tailings samples were tested. Samples from other mining areas and processes should be examined for physico-chemical properties to determine seal formation requirements. Tests should then be made to determine radon and radium sealing capability.

- With water dilution or dilution with nonionic asphalt emulsion, one should be capable of achieving greater penetration, thus providing a thicker, more mechanically stable seal. This could result in a material cost savings.

- The use of airblown asphalt as a feed stock for preparation of asphalt emulsion should be investigated since it would potentially increase the long-term stability of the asphalt emulsion (resistance to oxygen and ozone).

- Tailings surface wetness requirements must be established to provide thin continuous asphalt emulsion films of optimum penetration.

- The effect of various controllable variables (such as seal thickness) on radon and radium sealing capability should be evaluated. 
APPLICATION TECHNOLOGY

Pumping equipment is available for transfer of cationic asphalt emulsion, but pressure pump equipment for airless spray application has not been demonstrated to our knowledge. A11 laboratory pumping and spray equipment plugged where cationic asphalt emulsion was involved. If feasible use of boom spray equipment for vehicular inaccessible and sloped areas would be desirable. Once capable cationic asphalt emulsion spray equipment is obtained, operating parameters must be established to minimize or eliminate bubble formation to provide continuous pin-hole free films.

Another area of needed application technology is for thin asphalt emulsion tailings radon seals which require a protective cover to prevent ultraviolet radiation degradation. Soil/sand is a logical choice, but placing this material over the asphalt film without vehicular contact with the film presents a problem. Therefore, a minor study is needed to select the optimum choice to accomplish the task.

\section{FIELD MEASUREMENTS}

Short Term

Near completion of the laboratory effort, a field installation of radon seal should be made to demonstrate transfer of laboratory success to the field under field application technology. Radon emanation reduction measurements enable calculations of the process cost.

\section{Long Term}

Field installations should be made in convenient tailings locations to observe degradation rates of cationic asphalt emulsion films with and without top cover. Primary degradation measurement of interest would be radon level changes as measured with portable equipment.

\section{CONTOUR REQUIREMENTS}

Sealing the tailings surface to radon emanation also provides surface water sealing requiring drainage considerations. In arid regions contouring prior to sealing could serve as a water catchment. Shallow-rooted vegetative growth on top soil cover could provide a wind erosion deterrent. 
Contour slope requirements must be considered for potential problems of sliding cover materials after severe wetting.

Where minimum top cover but long-life radon seals are desired, it is necessary to prepare seals 1.92 to $2.54 \mathrm{~cm}(3 / 4$ to $1-i n$.$) thick and cover$ these seals with wind-stable, ultraviolet reflective aggregate. In general adequate top cover materials are expected to be available nearby and may be transported at modest cost. With thin ultraviolet protective top cover materials, vehicular traffic must be controlled.

\section{STABILITY}

\section{Chemical}

Asphalt degrades upon ultraviolet and oxygen exposure. The ultraviolet degradation rates are higher than with oxygen but are easily curtailed with soil top cover. To obviate effects of oxygen requires anaerobic burial depths of approximately $1.4 \mathrm{~m}(4.5 \mathrm{ft})$ or with high humus content $0.8 \mathrm{~m}(2.5 \mathrm{ft})$. If an inhibitor could be incorporated into the emulsion, a considerable amount of top cover placement costs could be saved. Sufficient understanding of the oxygen-produced degradation mechanism would be needed to specify inhibitors and their quantities. Air-blown molten asphalt resulting in considerable increased ketonic, carboxylic acid, and etheric content is used as a stabilizing procedure in the road asphalt industry. The possibility of using air-blown asphalts as feedstock for cationic emulsion preparation is suggested but, to our knowledge, has never been attempted.

\section{Mechanical}

To our knowledge the mechanical stability of thin asphalt emulsion films with soil top cover to vehicular traffic has never been determined. Highway programs involving cationic-asphalt emulsion uses subsoil vapor seals which are covered with layered roadbed materials for load distributed strength. For vehicular traffic capability over tailings areas the overburden depth requirements as a function of unit area weight exposure to maintain radon seal integrity must be determined. The tradeoff of increased seal thickness by penetration improvement with lower overburden thickness requirements is obvious. 


\section{REFERENCES}

1. ERDA, Summary Report - Phase 1, Study of Inactive Uranium Mill Sites and Tailings Piles. Energy Research and Development Administration, Washington, DC, p. 7, October 1974.

2. Ford, Bacon and Davis, Phase II Title 1 Engineering Assessment of Inactive Uranium Mill Tailings - Vitro Site. Salt Lake City, UT, p. 2-13, Apri1 30, 1976.

3. S. R. Borrowman and P. T. Brooks, "Radium Removal From Uranium Ores and Mill Tailings." USBM Report of Investigation 8099, 1975.

4. Federal Water Pollution Control Administration, Disportion and Control of Uranium Mill Tailings Piles in the Colorado River Basin. U.S. Department HEW, Denver, CO, March 1966.

5. Hampe1, C. A., Editor, The Encyclopedia of the Chemical Elements. Reinhold Book, New York, NY, 1968.

6. E. D. Simons, Guide to Uncommon Metals. Hart Publishing Co., New York, NY, 1967.

7. H. W. Kirby and M. L. Salutsky, The Radiochemistry of Radium. National Research Council, Clarksville, MD, December 1964.

8. Perry's Chemical Engineering Handbook, 4th Edition, McGraw-Hill, New York, NY, 1969.

9. Handbook of Chemistry and Physics, 57th Edition, Chemical Rubber Co., Cleveland, $\mathrm{OH}, 1976$.

10. Federal Radiation Council, Guidance for the Control of Radiation Hazards in Uranium Mining. Report No. 8, Washington, DC, September 1967.

11. U.S. Code of Federal Regulations, vol. 41, no. 133, July 9, 1976.

12. U.S. Code of Federal Regulations, 10CRF20, Appendix B, Table 1, p. $158,1976$.

13. J. N. Dybalski, The Chemistry of Asphalt Emulsions. Fifty-fifth Annual Meeting Transportation Research Board, January 1976.

14. R. W. Rogers, Cuneiform Parallels to the 01d Testament. Eaton and Mains, New York, NY, p. 91, 135, 1912.

15. D. A. McKenzie, Myths of Babylonia and Assyria. Gresham Publishing Co., London, p. 191, 1916.

16. Memoires de la Delegation en Perse, published under the direction of M. J. de Morgan, Vol. II, Plate IX; Vol. VIII, p. 162; Vol. X (1908), Plate I; Vol. XIII, Plates XXXIII and XXXVI, published by Ernest Leroux, Paris, 1900.

17. M. J. de Morgan, Comptes Rendus de 1'Academie d'Inscriptions. pp. 398-399, Figures 7 and 2 , JuTy 1907. 
18. S. H. Langdon, Excavations at Kish. 4 Volumes, P. Geuthner, Paris 1924.

19. S. H. Langdon, "Ausgrabungen in Babylonien seit 1918," Der alte Orient, 26, J. C. Heinrichs, Leipzig, 1927.

20. L. C. Watelin, Rapport des fouilles de Kish," Journal Asiatique, p. $107,1929$.

21. J. E. Hackford, S. Lawson, and P. E. Spielmann, "An Asphalt Ring from Ur of the Chaldees," J. Inst. Petrol. Tech., 17:738, 1931.

22. R. J. Forbes, "Note on a Lump of Asphalt from Ur," J. Insti. Petrol. Tech., 22:180, 1936.

23. H. R. Hall and C. L. Woolley, Ur Excavations. Vol. I ("Al-Ubaid"), London, 1927.

24. C. L. Woolley, "Excavations at Ur," Antiquaries' Journal, 8: I, 1928.

25. S. H. Langdon, "Ausgrabungen in Mesopotamien, seit 1918," Der alte Orient, 25: I, 1928.

26. H. R. Ha11, Ur Excavations. Vol. I, "Al-Ubaid" (el Obeid), Oxford 1927.

27. C. L. Woolley, "Excavations at Ur," Antiquaries' Journal, 1928.

28. C. L. Woolley, Digging up the Past. Ernest Benn Ltd., London, 1930.

29. C. L. Woolley, Ur und die Sintflut. F. A. Brockhaus, Leipzig and Stuttgart, 1932.

30. T. Fish, "About Building in Ur III, (Aspects of Sumerian Civilization as Evidenced on Tablets in the John Ryland's Library." Bul1, John Ryland's Library, 13, 134, 1934.

31. C. L. Woolley, Ur Excavations. Oxford Press, London, 1934.

32. H. de Sarzec and L. A. Heuzey, Decouvertes en Chaldee. 2 volumes, Paris, 1884-1919. L. W. Heuzey, Nouvelles fouilles de Tello.

E. Leroux, Paris, 1910-1914.

33. Ernest Leroux, Foundation Eugene Piot, Monuments et Memories. Paris, Volume VI, 1899, and Volume VII, 1900.

34. M. Jastrow, Jr., The Civilization of Babylonia and Assyria. J. B. Lippincott Co., Philadelphia, PA, pp. 394-395, 1915.

35. C. L. Woolley, Vor 5000 Jahren. Leipzig, 1930; Ur und die Sintflut, F. A. Brockhaus, Leipzig and Stuttgart, 1932.

36. R. J. Forbes, Untersuchungen Ueber die altesten Anwendungen von Bitumen in Mesopotamien. Bitumen, 3, 9, 41 and 63, 1935.

37. F. J. Nellensteyn and J. Brand, Asphalt Found in Mesopotamien Excavations. Chem. Weekbalt, 33:257, 1936.

38. R. J. Forbes, Het Bitumen in de Verfindustrie. Verfkroniek, 9:263, 1936. 
39. H. Frankfort, Tell Asmar and Khafaje - The First Season's Work in Eshnunna 1930-31. Thorkeild Jacobsen and Conrad Preusser, Univ. of Chicago Oriental Inst. Communication No. 13, Univ. of Chicago Press, Chicago, IL, 1932.

40. H. Frankfort, Tell Asmar, Khafaje and Kharsabed - Second Preliminary Report of the Iraq Expedition. Univ. of Chicago Oriental Inst. Communication No. 16, Univ. of Chicago Press, Chicago, IL, 1933.

41. H. Frankfort, Iraq Excavations of the Oriental Institute 1932/33 Third Prel iminary Report of the Iraq Expedition. Univ. of Chicago Oriental Inst. Communication No. 17, Univ. of Chicago Press, Chicago, IL, 1934.

- H. Frankfort, Oriental Institute Discoveries in Iraq, 1933-34, Fourth Preliminary Report of the Iraq Expedition.

43. H. Frankfort, Program of the Work of the Oriental Institute in Iraq, 1934-35, Fifth Preliminary Report of the Iraq Expedition.

44. A. Watelin, "Rapport des fouilles de Kish." Journal Asiatique, p. $107,1929$.

45. A. Falkenstein, Archaische Texte aur Uruk. Harrassowitz, Leipzig, 1936.

46. S. van Westrum, U.S. Patent 956,009. Road Building, 1910.

47. C. Philipp, Tecnisch veruendbare Emulsionen Bd. I. Bituminose Emulsionen. Berlin, 1938.

48. M. B. Sears et a1., Correlation of Radioactive Waste Treatment Costs and the Environmental Impact of Waste Effluents in the Nuclear Fuel Cycle for Use in Establishing "As Low as Practicable" Guides - Milling of Uranium Ores. ORNL-TM-4903, Oak Ridge National Laboratory, Oak Ridge, TN, Vol. 1, May 1975.

49. U.S. Department of Health Education and Welfare, Disposition and Control of Uranium Mill Tailings Piles in the Colorado River Basin, Federal Water Pollution Control Administration, Region VIII, U.S. Department of Health, Education, and Welfare, Denver, CO, March 1966.

50. U.S. Environmental Protection Agency. Program 25 Soil Results (computer printout), U.S. Environmental Protection Agency, National Environmental Research Center, Las Vegas, NV, March 1974.

51. E. M. Lederer, J. M. Hollander and I. Perlman, Table of Isotopes. 6th Edition, John Wiley and Sons, Inc., New York.

52. Potential Radiological Impact of Airborne Releases and Direct Gamma Radiation to Individuals Living Near Inactive Uranium Mill Tailings Piles. EPA-520/1-76-001. U.S. Environmental Protection Agency, Environmental Analysis Division, Washington, DC, January 1976.

53. M. B. Sears et al., Correlation of Radioactive Waste Treatment Costs and the Environmental Impact of Waste Effluents in the Nuclear Fuel Cycle for Use in Establishing "As Low as Practicable" Guides - MilTing of Uranium Ores. ORNL-TM-4903, Oak Ridge National Laboratory, Oak Ridge, TN, Vol. 1, May 1975. 
54. K. J. Schiager, "Analysis of Radiation Exposures on or Near Uranium Mill Tailings Piles," Radiation Data and Reports, 15, U.S. Environmental Protection Agency, 7, July 1974.

55. Gallaway, "Asphalt Research at Texas A\&M," Presented at 13th Annual Research Meeting, ERDA Research Center, Laromie, WY, July 16, 1976.

56. R. P. Lutiman, "Debonding Within Water-Saturated Asphalt Concrete Due to Cyclic Effects." American Chemical Society Symposium on Science of Asphalt in Construction, Los Angeles, CA, March 28-Apri1 2, 1971.

57. H. J. Fromm, "The Mechanisms of Asphalt Stripping from Aggregate Surfaces." Presented at Annual Meeting of Association of Asphalt Paving Technologists, Williamsburg, VA, February 25-27, 1974.

58. P. L. Koehmstedt, "Water Induced Damage to Asphalt Concrete." FHWA Water in Pavements Workshop, Portland, OR, November 1973.

59. R. A. Jiminez, Asphalt Emulsion Treated Aggregate. Transportation and Traffic Institute, TRIS 083114, Arizona University, Tucson, AZ.

60. R. Hundeshogen, "The Behavior of Asphalt Bitumen and Coal Tar Pitch Towards Microorganism." Bantenschutz 6:141, 1935.

61. R. W. Traxlen, "Bitumen Attach by Microorganisms." Ind. and Engineer Chem., 58(6):59, June 1966 .

62. T. K. Jones, "Effects of Bacteria and Fungi on Asphalt," Material Protection. p. 39, December 1965.

63. F. J. Nellensteyn, "Solubility of Asphalt Bitumen and Asphaltenes in Mixed Solvents." Chem Weekbald, 28:313, 1931.

64. H. G. Hammon, K. Ernst, J. R. Gaskill, J. C. Newton, and C. J. Morris, Development and Evaluation of Radon Sealants for Uranium Mines. UCRL-51818, 1975.

65. Handbook of Chemistry and Physics. Chemical Rubber Publishing Company, p. 3088, Cleveland, $\mathrm{OH}$.

66. H. G. Hammon et al., Development and Evaluation of Radon Sealants for Uranium Mines. UCRL-51818, P. 11, May 21, 1975.

67. P. V. Danckwerts, "Absorption by Simultaneous Diffusion and Chemical Reaction into Particles of Various Shapes and into Falling Props." Trans. Faraday Society, 47:1014-23, 1951.

68. A. P. Anderson and K. A. Wright, "Permeability and Absorption Properties of Bituminous Coatings." Industrial and Engineering Chemistry, 33(8): $991,1941$.

69. R. Grader, "The Determination of Water Permeability of Bitumen." Asphalt Teen Strassenbautech, 39:467-70, 1939.

70. Szalo Piroska, "A Simple Experiment for the Determination of the Water Permeability of Bitumen." Magyas Fiz. Folijoirat 6:477-81, 1958. 
71. R. L. Taylor, D. B. Herrmann, A. R. Demp, "Diffusion of Water Through Insulating Material." Industrial and Engineering Chemistry, 28(11): 1255, 1936.

72. A. V. Bykhovskii, N. T. Chesnokov, S. S. Pokrovskii, G. N. Khorev, and P. I. Yusov, Experience with Radon Control in Mining. (Translated from Russian), Bureau of Mining, Dept. Interior, Amerind Publication Co., New Delhi, India, 1974.

73. Carpenter, "Solution and Diffusion in High Polymers." Trans Faraday Society, 43:529, 1947.

74. H. H. Lowry, G. T. Kohman, "The Mechanics of the Absorbties of Water in Rubber," J. Phys. Chem., 31:23, 1927.

75. T. K. Kwei and W. M. Arnheim, "Linear Free Energy Relationship in the Diffusion of Gases through Polymer Filters." J. Poly. Science, Part A, 2: $957,1964$.

76. T. K. Kwei and W. M. Arnheim, "Solubility of Non-Polar Gases in Polymers: Some New Consideration." J. of Poly. Science, Part A, 2: $1873,1964$.

77. R. M. Barrer, "Some Properties of Differsion Coefficient in Polymers." J. Phys. Chem., 61:178, 1957.

78. R. M. Barrer, G. Skirrow, "Transport and Equilibrium Phenomena in GasElastomer Systems-I-Kinetic Phenomena." J. of Poly. Science, $3: 549$, 1948. 


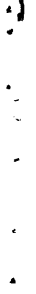


APPENDIX A

RADIUM-RADON TRANSPORT THROUGH ASPHALT EMULSION 


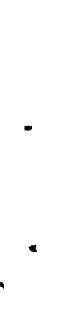


APPENDIX A

RADIUM-RADON TRANSPORT THROUGH ASPHALT EMULSION

As waste products of the uranium recovery process, both radium and radon can be transported through a uranium mill tailings pile. Radium has been loosened from its rock matrix, and is more leachable, while radon, the gaseous decay product of radium, can easily diffuse through the uranium tailings. Asphalt emulsion can seal the tailings pile, greatly reducing the release of radium and radon.

The potential transport of radon and radium through an asphalt emulsion tailings seal is reviewed in this section. The diffusion of gases and liquids through asphalt and polymers is also reviewed. In order to characterize the diffusion properties of radium and radon, an attempt will be made to correlate information obtained from diffusion studies using compounds different from radium and radon. Due to its high molecular chains, the asphalt emulsion can be likened to an amorphous polymer. With this in mind, we will be able to describe the diffusion characteristics of the asphalt emulsion. The diffusion of radon and radium will be described by looking at the rates of diffusion for $\mathrm{O}_{2}$ and $\mathrm{H}_{2} \mathrm{O}$ through asphalt and polymers.

\section{DIFFUSION MODEL}

The system is one dimension molecular diffusion through a solid. Assuming that the diffusion proceeds in the $X$ direction, Fick's law is written as

$$
J_{A}=-D \frac{d c}{d x}
$$

$J$ is the flux of $A$ through a given area, $D$ is the diffusivity coefficient and $C$ is the concentration of $A$. The minus sign indicates that the movement is in the direction of decreasing concentration. Fick's first law holds for when $\frac{d c}{d x}$ is a constant, but due to the fact $\frac{d c}{d x}$ is not a constant, we cannot apply it here. However, we are allowed to use Fick's second law: 
excessive bulging occurred. A decision was made to dry all tailings specimens prior to testing to facilitate nitrogen-radon flow.

\section{Test 2}

It became evident in this experiment that a porous spacer was needed to prevent upward seal bulging from the nitrogen-radon pressure. It was also difficult to achieve and maintain a positive 0.014 to $0.021 \mathrm{~kg} / \mathrm{cm}^{2}(0.2$ to 0.3 psi) pressure differential. This problem was solved by placing needle valves at the inlet and exit points of the $150 \mathrm{~cm}^{3} / \mathrm{min}$ nitrogen carrier line above the seal. In effect, this created an adjustable flow-through pressure drop comparable to that encountered beneath the seal.

During the experiment, valves were adjusted several times to maintain the 0.014 to $0.021 \mathrm{~kg} / \mathrm{cm}^{2}(0.2$ to $0.3 \mathrm{psi})$ seal differential pressure. During adjustments, the seal differential pressure reached as high as $0.021 \mathrm{~kg} / \mathrm{cm}^{2}$ ( 0.31 psi) resulting in a center bulge height of approximately $25 \mathrm{~mm}$ ( 1 in.). Several bulge heights of 13 to $19 \mathrm{~mm}$ (1/2 to $3 / 4 \mathrm{in}$.) were encountered during valve adjustments in the course of the experiment. Since radon was not detected above the seal, the temporary bulging apparently did not affect the seal integrity.

\section{Test 3 (Phase I)}

A pump failed during a weekend in the above-seal nitrogen system which resulted in 2 days of operation with the seal at $0.02 \mathrm{~kg} / \mathrm{cm}^{2}(0.3 \mathrm{psi})$ negative pressure. However, no radon was detected above the seal during this phase of the experiment.

\section{Test 3 (Phase II)}

The seal test chamber was then exposed to a ${ }^{60}$ Co $(2050 \mathrm{R} / \mathrm{hr})$ source at $72^{\circ} \mathrm{F}$ unti $105,000 \mathrm{R}$ dosage was achieved. The test chamber was reconnected into the radon test system and the two gas flow systems were initiated. Radon was not detected above the seal throughout this phase of the experiment.

\section{Test 3 (Phase III)}

The seal chamber was exposed to cyclic freeze/thaw conditions ( 0 to $72^{\circ} \mathrm{F}$ ) for 19 cycles and was then reconnected into the test system and the two gas 


$$
\frac{d c}{d t}=D \frac{d^{2} c}{d x^{2}}
$$

which must be modified for radon due to its short half-life. This is done by adding $-\lambda c$ to Equation (5) forming Equation (6).

$$
\frac{d c}{d t}=D \frac{d^{2} c}{d x^{2}}-\lambda c
$$

$\lambda$ is the disintegration constant for the specie. The equation holds for any decaying nuclide. Danckwerts ${ }^{(67)}$ has solved this partial differential equation with the following boundary condition:

$$
\begin{array}{lll}
x=0 & c=c_{1} & \text { for at } t \\
t=0 & c=0 & \text { for } x>0 \\
t>0 & c=0 & x=l
\end{array}
$$

The resulting equation is:

$C=C_{1}\left(1-\frac{x}{\ell}\right)-\frac{2 C_{1} \lambda \ell^{2}}{D \pi^{3}} \sum_{n=1}^{\infty} \frac{1}{n} \sin \frac{n \pi x}{\ell}\left[\frac{1+\frac{D \pi^{2} n^{2}}{\lambda \ell^{2}} e^{-\left(\frac{D \pi^{2} n^{2}}{\ell^{2}}+\lambda\right) t}}{n^{2}+\frac{\lambda \ell^{2}}{D \pi^{2}}}\right]$

The unknowns for the equation are $D, C_{1}$, and $\lambda$. The value of $\lambda$ for radon is $0.182 /$ day, and the value of $\lambda$ for radium is $1.17 \times 10^{-6} /$ day. $c_{1}$ for radium is assumed to be equal to the radium concentration found in the tailings. The concentration of radium in the Vitro tailings ranges between 1.7 to $34.5 \times 10^{-10} \mathrm{~g} / \mathrm{cm}^{3}$. (2) An equilibrium exists between the radium concentration and the radon concentration. Equation (11) shows the relationship:

$$
\lambda A N A=\lambda B N B
$$

where $N A$ and $N B$ are the number of molecules/volume and $\lambda A$ and $\lambda B$ are the disintegration constant.

The ratio of $N A: N B$ is $\lambda B / \lambda A$ which is equal to $6.43 \times 10^{-6}$ for our case. Using this fact the radon concentration is between $1.08-21.8 \times 10^{-15} \mathrm{~g} / \mathrm{cm}^{3}$. 
Equation (10) can now give the concentration of the species in the asphalt layer for any plane normal to the direction of diffusion for Equation (4). If we differentiate Equation (10) with respect to $x$ and multiply by $-D$ we obtain:

$$
J_{A}=\frac{D C_{1}}{l}+\frac{2 C_{1} \lambda l}{\pi^{2}} \sum_{n=1}^{\infty} \cos \frac{n \pi x}{l}\left[\frac{1+\frac{D \pi^{2} n^{2}}{\lambda \ell^{2}} e^{-\left(\frac{D \pi^{2} n^{2}}{\ell^{2}}+\lambda\right) t}}{n^{2}+\frac{\lambda l^{2}}{D \pi^{2}}}\right]
$$

We are interested in the amount of material passing through the asphalt emulsion layer, so we evaluate Equation (12) at $x=l$, where $\ell$ is the thickness of the layer. Upon evaluating the series and looking at a time in the future, we arrive at the steady-state flux of material through the asphalt:

$$
\mathrm{J}_{\mathrm{A}}=\frac{D C_{1}}{\ell} \cdot \frac{\sqrt{\frac{\lambda}{D} \cdot \ell}}{\sinh \sqrt{\frac{\lambda}{D} \cdot \ell}}
$$

The flux through the asphalt depends on the diffusion coefficient, film thickness, and decay coefficient. The above equations are valid for free diffusion, that is, no large pressure difference between the sides of the layer.

To consider the case where there is forced diffusion caused by a pressure differential across the layer, the flux of material through the barrier due to a pressure difference is defined as $\mathrm{N}$ :

$$
\begin{aligned}
& \qquad N=\frac{K P}{L}\left(\frac{g}{\mathrm{~cm}^{2} h r}\right) \\
& K=\text { Permeability constant }\left(\frac{\mathrm{g}}{\mathrm{cm} \mathrm{mm} \mathrm{Hg} \mathrm{hr}}\right) \\
& P=\text { Pressure difference } \mathrm{mm} \mathrm{Hg} \\
& L=\text { Layer thickness, } \mathrm{cm}
\end{aligned}
$$


There has been some work on determining diffusion and permeability constant for asphalt. (68-71) They have been mainly for elements and compounds different from radium and radon. An attempt to correlate the data for our use will be made.

\section{DIFFUSION IN ASPHALT, BITUMINOUS MATERIAL, AND POLYMERS}

The permeability of asphalt to water and oxygen ${ }^{(68-71)}$ has been determined. The Russians have reported a value for the diffusion constant for radon through a bitumen-latex layer. ${ }^{(72)}$ The diffusion and permeability constants for water, oxygen, and radon are listed in Table A-1.

TABLE A-1. Permeability and Diffusion Constants for Water, Oxygen, and Radon

$$
\begin{array}{lr}
\begin{array}{l}
\text { Permeability, } \\
\mathrm{g} / \mathrm{hr} \mathrm{cm} \mathrm{mm} \mathrm{Hg}
\end{array} & \text { Water }-2.42 \times 10^{-8} \\
\begin{array}{c}
\text { Diffusion, } \\
\mathrm{cm} / \mathrm{sec}
\end{array} & 0_{2}-4 \times 10^{-10} \\
& \text { Radon }-1.2 \times 10^{-7}
\end{array}
$$

The higher permeability of water, as indicated in Table 16, is due to its high solubility in asphalt. 0xygen reacts with the asphalt retarding its transport through the asphalt. Since radon is inert, it will diffuse through the asphalt with no chemical interference. The permeability of the asphalt to water can be reduced by removing impurities in the asphalt which gives the asphalt higher water solubility; the normal solubility of water in asphalt is about $242 \times 10^{-5} \mathrm{~g} \mathrm{H}_{2} \mathrm{O} / \mathrm{cm}^{3}$ asphalt $\mathrm{mm} \mathrm{Hg} .{ }^{(68)}$ The permeability of the asphalt is a function of the diffusion constant and the solubility constant. The equation for permeability is:

$$
P=D S
$$

where $P=$ Permeability Constant

$D=$ Diffusion Constant

$S=$ Solubilities (Henry's Law Constant) 
Using the values listed in Table A-l for the permeability and solubility, the diffusion constant for water in asphalt is $2.99 \times 10^{-7} \mathrm{~cm}^{2} / \mathrm{sec}$. This is about twice the value reported by the Russians for radon.

To find the approximate diffusion coefficient for $\mathrm{O}_{2}$ in asphalt, the solubility of water and $\mathrm{O}_{2}$ in rubber was compared. Both rubber and the asphalt material are made of polymers and also contain trace elements. The solubility (Henry's Law Constant) for $\mathrm{O}_{2}$ in rubber was $1.559 \times 10^{-7} \mathrm{~g} \mathrm{O}_{2} /$ $\mathrm{cm}^{3} \mathrm{~mm} \mathrm{Hg}{ }^{(73)}$ while the solubility of $\mathrm{H}_{2} \mathrm{O}$ was $2.232 \times 10^{-4} \mathrm{~g} \mathrm{H}_{2} \mathrm{O} / \mathrm{cm}^{3} \mathrm{~mm} \mathrm{Hg}$. As with the asphalt, the higher water solubility was caused by the impurities found in the rubber. The solubility of two gases in a polymer have a definite ratio which depend only on the nature of the gases. Using this fact, it was assumed that the solubility ratio found in rubber $6.985 \times 10^{-4}$ was identical to the ratio found in asphalt. With these facts, the solubility of $\mathrm{O}_{2}$ in asphalt is $1.69 \times 10^{-6} \mathrm{~g} \mathrm{O}_{2} / \mathrm{cm}^{3} \mathrm{~mm} \mathrm{Hg}$. Using the definition of permeability, the diffusion coefficient of oxygen through asphalt is $6.57 \times 10^{-6} \mathrm{~cm}^{2} / \mathrm{sec}$. Therefore, the diffusion of oxygen is 50 times greater than radon.

Studies state that the $\log$ of the diffusion constant is a linear function of the energy of activation, $\Delta H .(75-78)$ It has also been determined that the energy of activation can be separated into two parts: one part depends only on the properties of the polymers, the other depends only on the properties of the diffusing molecule. ${ }^{(76)}$ It has been stated that the diffusion constant could be expressed as:

$$
\log D=K \alpha-4.56-\beta
$$

where $k=a$ function of the diffusion gas only

$\alpha=a$ function of the polymers only

$\beta=a$ constant for the polymers

The variable $K$ is defined as $0.0763 d^{2}$, where $d$ is the diameter of the diffusing molecule. ${ }^{(75)}$ The a value is determined by experimental work and is a constant for a given polymer. It will be possible to find the $\alpha$ value for the asphalt by knowing the diffusion constant and the $K$ factor 
for either $\mathrm{O}_{2}$ or water. The theory behind this equation is that there are open spaces in the polymer structure through which the molecule diffused. The factor $K$ is a measure of the size of molecule that is passing through the open spaces. The factor $\alpha$ is a measure of the resistance to: 1) diffusion produced by the polymer, and 2) enlargement of the gaps in the polymer structure. The term $\beta$ is a measure of polymer interchain movement. The values estimated for $\alpha$ and $\beta$ for the asphalt are -2.8973 and -1.975 , respectively. The value of $K$ for radon is 1.6 and for radium ions is 0.598 . With this value of $\mathrm{K}$, the diffusion constant for radium is $9.6 \times 10^{-5} \mathrm{~cm}^{2} / \mathrm{sec}$. The assumed values for $D$, diffusion constants, in asphalt for radium and radon are:

- Radon - $1.2 \times 10^{-7} \mathrm{~cm}^{2} / \mathrm{sec}$,

- Radium - $9.6 \times 10^{-5} \mathrm{~cm}^{2} / \mathrm{sec}$.

Based on the one dimensional diffusion model and on diffusion in asphalt, bituminous material and polymers, estimates were made for the amount of radon and radium diffusing through an asphalt emulsion layer. The assumptions used are the initial concentration of radium and radon in the tailings of $3.45 \times 10^{-9} \mathrm{~g} / \mathrm{cm}^{3}$ and $2.18 \times 10^{-14} \mathrm{~g} / \mathrm{cm}^{3}$, respectively. The decay constants are $0.182 /$ day for radon and $1.17 \times 10^{-6} /$ day for radium. The diffusion constants are listed above. Estimated quantities of radon and radium that would potentially transport through various thicknesses of asphalt emulsion are shown in Table A-2.

TABLE A-2. Radon and Radium Diffusion Rates Through Asphalt Emulsion

Asphalt Emuision Thickness

\begin{tabular}{|c|c|}
\hline $\mathrm{cm}$ & in. \\
\hline 0.3175 & $(1 / 8)$ \\
\hline 0.635 & $(1 / 4)$ \\
\hline 1.27 & $(1 / 2)$ \\
\hline 2.54 & 11 \\
\hline 5.08 & ( 2 \\
\hline
\end{tabular}

Radon Transport

$\begin{array}{ll}\frac{\mathrm{g} / \mathrm{cm}^{2} \mathrm{sec}}{6.23 \times 10^{-21}} & \frac{\rho \mathrm{Ci} / \mathrm{cm}^{2} \mathrm{sec}}{9.5 \times 10^{-4}} \\ 1.54 \times 10^{-21} & 2.3 \times 10^{-4} \\ 1.07 \times 10^{-22} & 1.6 \times 10^{-5} \\ 5.23 \times 10^{-25} & 8 \times 10^{-8} \\ 1.25 \times 10^{-29} & 1.9 \times 10^{-12}\end{array}$

Radium Transport

\begin{tabular}{ll}
$\frac{\mathrm{g} / \mathrm{cm}^{2} \mathrm{sec}}{2 \mathrm{Ci} / \mathrm{cm}^{2} \mathrm{sec}}$ \\
\hline $3.90 \times 10^{-16}$ & $3.9 \times 10^{-4}$ \\
$1.95 \times 10^{-16}$ & $1.9 \times 10^{-4}$ \\
$9.76 \times 10^{-17}$ & $9.76 \times 10^{-5}$ \\
$4.88 \times 10^{-17}$ & $4.88 \times 10^{-5}$ \\
$2.44 \times 10^{-17}$ & $2.44 \times 10^{-5}$
\end{tabular}


In order to better understand the results presented in Table A-2, the results will be expressed in other terms. Looking at the $3.2-\mathrm{mm}$ seal, it would take $5.1 \times 10^{12} \mathrm{yr}$ for $1 \mathrm{~g}$ of radon to pass through $1 \mathrm{~cm}^{2}$ area of asphalt sealed tailings. An area of $5.1 \times 10^{8} \mathrm{~m}^{2}\left(197 \mathrm{mile}^{2}, 1 / 6\right.$ the size of Rhode Island) would emit $1 \mathrm{~g}$ of radon in $1 \mathrm{yr}$ ( $1 \mathrm{~g}$ of radon equals 1.53 $\times 10^{5} \mathrm{Ci}$ ). Therefore, it would take $3.32 \times 10^{7} \mathrm{yr}$ for $1 \mathrm{Ci}$ of radon to be released from $1 \mathrm{~cm}^{2}$ of sealed tailings and $1 \mathrm{Ci}$ of radon will be released from $3.32 \times 10^{3} \mathrm{~m}^{2}$ of tailings/yr. Radon decays quickly which reduces the actual amount of radon that will be found in the air above the tailings. To have $1 \mathrm{~g}$ of radon in the air at equilibrium conditions, it would require a tailings pond with an area of $3.38 \times 10^{10} \mathrm{~m}^{2}\left(13,055 \mathrm{mile} \mathrm{e}^{2}, 10.75\right.$ times the size of Rhode Island). At equilibrium conditions 1 Ci would be released from $2.21 \times 10^{5} \mathrm{~m}^{2}\left(0.08 \mathrm{miles}^{2}\right)$ of tailings area.

The radium has been assumed to be a free ion to this point, but in reality the radium is contained in a molecule. The molecular specie could be radium sulfate, $\mathrm{Ra}\left(\mathrm{SO}_{4}\right)$, radium carbonate, $\mathrm{Ra}\left(\mathrm{CO}_{3}\right)$, or another specie. The predominant radium compound found in tailings from sulfuric acid processing is radium sulfate, a compound that is highly insoluble in most aqueous solutions. (3) The sizes of these molecules are very large compared to either the radium ion or a radon molecule. Therefore, it is assumed that the radium flux through the asphalt will be equal to or less than the flux of radon through the layer.

\section{THE LEACHING OF RADIUM THROUGH THE ASPHALT}

Leaching is the removal of a molecular specie by a liquid. In the case of uranium tailings, the leaching liquid is primarily water. It has been found that the flow of molecules through asphalt emulsion is hampered when there is moisture present in the asphalt. This is due to the open gaps in the asphalt being filled with water molecules which reduces the open space available for the movement of the leached specie. Diffusion, as previously evaluated, assumes no water present in asphalt. Therefore, the maximum transfer of radium through the asphalt emulsion will occur by diffusion. Applying an asphalt emulsion layer to the tailings should seal the tailings pile, thus reducing the amount of radioactivity passing through the tailings. 



\section{APPENDIX B}

TYPICAL DATA TAKEN DURING LABORATORY EXPERIMENTS 
.

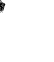

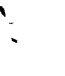


APPENDIX B

TYPICAL DATA TAKEN DURING LABORATORY EXPERIMENTS

Tables $B-1$ and $B-2$ present typical data taken during Experiment $6 R$. Data on Table $B-1$ includes pressure, flowrate and dose rate taken during this experimental test while data on Table B-2 includes average pressure, filter throughput, detector, counts/m and radon throughput, counts/ $\ell$.

Figures $B-1$ and $B-2$ present typical radon measurements made during Experiment 6R. Figure $B-1$ shows the radon levels above and below the seal and background. During Experiment $6 R$ a seal failed as can be seen in Figure $B-1$ where the radon level above the seal jumped rapidly. This caused the recorder pen to go off-scale, since it only had a range of $500 \mathrm{c} / \mathrm{m}$. Figure $\mathrm{B}-2$ shows background data for all three radon measurement systems showing effects of minor atmospheric inversion on radon background levels. 


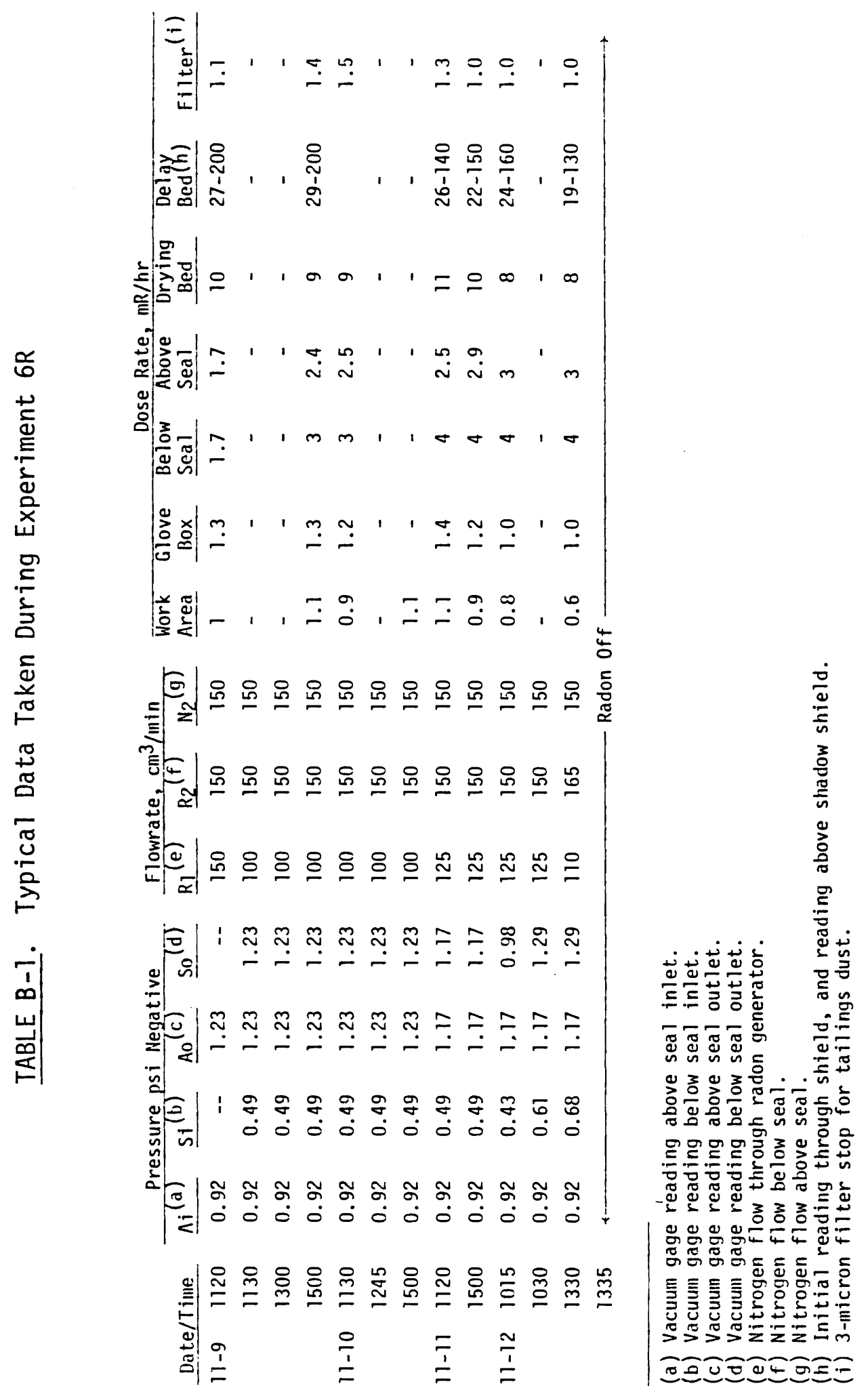


TABLE B-2. Experiment 6R (Vitro SS-10)

\begin{tabular}{|c|c|c|c|c|c|c|c|c|c|c|c|c|c|}
\hline \multirow[b]{2}{*}{ Date } & \multirow[b]{2}{*}{ Time } & \multicolumn{3}{|c|}{ Pressure Negative psi } & \multicolumn{3}{|c|}{$\begin{array}{l}\text { Filter Throughput, } \\
\text { l/m }\end{array}$} & \multicolumn{3}{|c|}{ Detector, $\mathrm{c} / \mathrm{m}$} & \multicolumn{3}{|c|}{$\begin{array}{l}\text { Radon Throughput, } \\
\mathrm{c} / \mathrm{l}\end{array}$} \\
\hline & & $\mathrm{S}_{1}+\mathrm{S}_{2} / 2^{(\mathrm{a})}$ & $A_{1}+A_{0} / 2^{(b)}$ & $\Delta P(c)$ & $A^{(d)}$ & $s^{(e)}$ & $B(f)$ & $A^{(g)}$ & $s^{(h)}$ & $B^{(i)}$ & $A^{(j)}$ & $\mathrm{S}$ & ${ }_{B}(k)$ \\
\hline \multirow[t]{4}{*}{$11-9$} & 1120 & - & 1.07 & - & 42.5 & 42.5 & 42.5 & 100 & 4400 & 230 & 5.65 & - & 5.41 \\
\hline & 1130 & 0.86 & 1.07 & 0.21 & 42.5 & 42.5 & 42.5 & 105 & 5000 & 230 & 5.93 & - & 5.41 \\
\hline & 1300 & 0.86 & 1.07 & 0.21 & 42.5 & 42.5 & 42.5 & 90 & 5000 & 225 & 5.08 & - & 5.29 \\
\hline & 1500 & 0.86 & 1.07 & 0.21 & 42.5 & 42.5 & 42.5 & 90 & 5000 & 210 & 5.08 & - & 4.94 \\
\hline \multirow[t]{3}{*}{$11-10$} & 1130 & 0.83 & 1.04 & 0.21 & 42.5 & 39.6 & 39.6 & 100 & 5000 & 220 & 5.65 & - & 5.17 \\
\hline & 1245 & 0.84 & 1.06 & 0.22 & 42.5 & 42.0 & 42.5 & 90 & 5000 & 220 & 5.08 & - & 5.17 \\
\hline & 1500 & 0.82 & 1.06 & 0.24 & 42.5 & 40.0 & 41.5 & 90 & 5000 & 190 & 5.08 & - & 4.57 \\
\hline \multirow[t]{2}{*}{$11-11$} & 1120 & 0.80 & 1.03 & 0.23 & 42.5 & 39.0 & 41.0 & 83 & 5000 & 200 & 4.68 & - & 4.87 \\
\hline & 1500 & 0.80 & 1.00 & 0.20 & 42.5 & 41.0 & 40.0 & 80 & 5000 & 180 & 4.52 & - & 4.50 \\
\hline \multirow[t]{3}{*}{$11-12$} & 1015 & 0.705 & 1.015 & 0.31 & 42.5 & 36.9 & 39.6 & 70 & 5000 & 180 & 3.95 & - & 4.51 \\
\hline & 1030 & 0.95 & 1.04 & 0.09 & 42.5 & 42.5 & 42.5 & 70 & 5000 & 175 & 3.95 & - & 4.11 \\
\hline & 1330 & 0.985 & 1.04 & 0.055 & 42.5 & 42.5 & 42.5 & 70 & 5000 & 160 & 3.95 & - & 3.76 \\
\hline
\end{tabular}

(a) Average pressure (negative) below seal.

(b) Average pressure (negative) above seal.

(c) Average pressure (positive) differential across seal.

(d) Gas flowrate through filter for above seal detector measurement.

(e) Gas flowrate through filter for below seal detector measurement.

(f) Gas flowrate through filter for background detector measurement.

(g) Countrate taken from above seal strip chart monitor.

(h) Countrate taken from below seal strip chart monitor.

(i) Countrate taken from background strip chart monitor.

(j) Radon throughput normalized to include radon response difference with background monitor.

(k) Radon throughnut background monitor. 


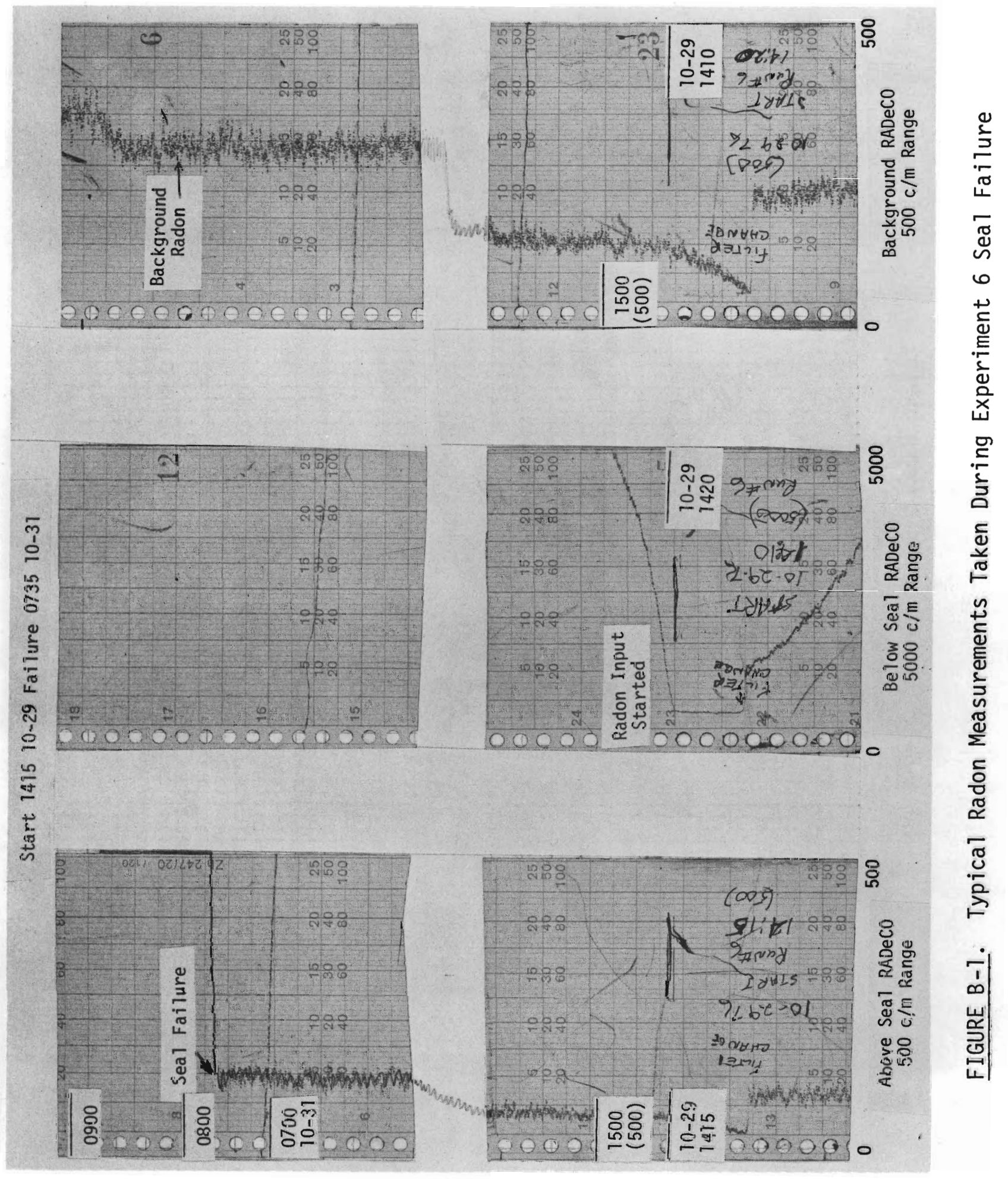




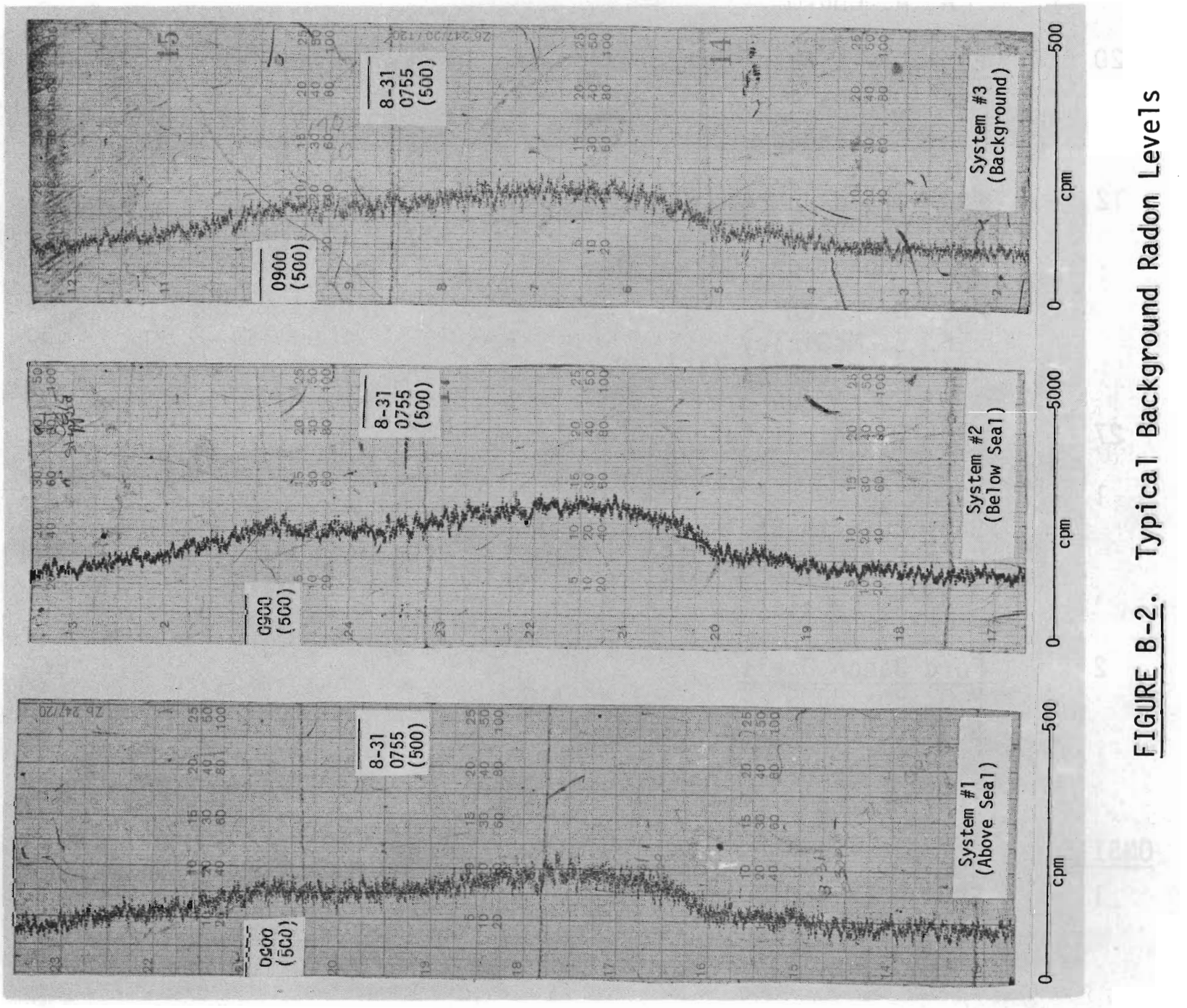


No. of

Copies

\section{OFFSITE}

1

\begin{tabular}{l} 
ERDA Chicago Patent Attorney \\
\hline 9800 S. Cass Avenue \\
Argonne, IL 60439
\end{tabular}

A. A. Churm

20

ERDA Division of Engineering and Safety Washington, DC 20545

R. H. Kennedy (20)

12 ERDA Grand Junction

P.0. Box 2567

Grand Junction, CO 81501

C. H. Roach

F. E. McGinley

J. G. Themelis (10)

27 ERDA Technical Information Center

$1 \quad$ ARMAK CO.

8401 W. 47th St.

McCook, IL 60525

J. N. Dybalski

2 Ford Bacon Davis

P.0. Box 8009

Salt Lake City, UT 84108

v. C. Rogers

P. McBeth

ONSITE

1 ERDA Richland Operations 
No. of

Copies

41 Battelle-Northwest

A. C. Abrams

F. T. Cross

D. K. Davis

G. W. Dawson

R. L. Dillon

J. N. Hartley (15)

J. H. Jarrett

P. L. Koehmstedt (10)

R. P. Marsha 11

R. E. Nightingale

P. C. Walkup

K. W. Winegardner

0. J. Wick

D. L. Williams

Technical Information Files (3)

Technical Publications (1) 